\title{
O Projeto UNI e os Movimentos \\ Populares de Saúde na Região Sul de Londrina.
}

ROGÉRIO RENATO SILVA

Dissertação apresentada ao Departamento de Prática de Saúde Pública da Faculdade de Saúde Pública da Universidade de São Paulo para obtenção do grau de Mestre.

Orientador

Professor Doutor

Francisco Bernardini Tancredi

São Paulo 
Aos meus pais e irmãos, pelo apoio constante. 


\section{AGRADECIMENTOS}

- Ao meu orientador, Prof. Dr. Francisco Bernardini Tancredi, pelo apoio nesses quase três anos, pelas sugestões e ensinamentos e, principalmente, por sua confiança.

- A Vinicia Campana Biancardi, por todas as coisas sem as quais eu não teria sido capaz de concluir este trabalho, principalmente pelo seu amor.

- Ao Prof. Dr. Márcio José de Almeida, pela constante orientação desde os anos da graduação em Londrina, por me apresentar essa Faculdade, pelas contribuições como membro da banca e pela amizade.

- Ao Prof. Aírton José Pétris, que me apresentou à Saúde Pública e à profissão farmacêutica, por ser amigo e compartilhar tantas coisas.

- À Prof. Dra. Fabíola Zioni, pelas grandes contribuições nas disciplinas cursadas, durante a etapa de qualificação e, sobretudo, pelo acompanhamento intenso no período que antecedeu à defesa.

- A Laura Feuerwerker, pela confiança depositada, pela consultoria permanente e por sua amizade.

- À Prof. Dra. Ana Maria Malik, pelos conselhos sempre tão prudentes, tão importantes.

- Aos companheiros de mestrado, em especial a Carla Ferraz, Sônia Pétris, Laura Schiesari, Cássia, Ana Maria, Ana Luiza e Patrícia Jaime, por compartilharem as angústias e as conquistas.

- Ao Laurindo e ao Etevaldo, pelo companheirismo e colaboração.

- Aos funcionários da CPG e da biblioteca da Faculdade de Saúde Pública, pela atenção sempre especial.

- A Sandra, pelo secretariado e atenção tão especiais.

- A todos os entrevistados, por me ajudarem a construir este trabalho.

- A Socorro Matos e David Capistrano, pela oportunidade que me deram.

- A Ana Rita Pederneiras, pelas contribuições e ensinamentos.

- Ao Fundo de Apoio à Pesquisa UNI, pelo auxílio financeiro. 


\section{RESUMO}

Silva RR. O Projeto UNI e os movimentos populares de saúde na região Sul de Londrina. São Paulo; 1999. [Dissertação de Mestrado - Faculdade de Saúde Pública da Universidade de São Paulo].

Este trabalho surgiu do interesse em compreender as relações entre o Projeto UNI: Uma Nova Iniciativa na Formação dos Profissionais de Saúde: União com a Comunidade e os movimentos populares de saúde a ele relacionados. Desenvolveu-se como um estudo de caso na região Sul do município de Londrina - PR, através da utilização de um método qualitativo que compreendeu análises documentais, entrevistas semi-estruturadas individuais e coletivas, bem como contribuições etnográficas, através das observações realizadas em campo. Os resultados obtidos foram descritos e discutidos dentro de sete categorias analíticas construídas e teoricamente relacionadas ao trabalho, sendo elas: articulação, autonomia, organização, parceria, cultura política, oposição e participação. A análise destas categorias revelou um significativo impacto positivo do Projeto UNI nas organizações comunitárias, ao longo dos últimos oito anos, as quais conquistaram maior capacidade e instrumentos de luta, ampliando sua participação na sociedade, principalmente nos espaços criados pelo Sistema Único de Saúde. 


\section{SUMMARY}

Silva RR. O Projeto UNI e os movimentos populares de saúde na região sul de Londrina [The UNI Project and the Health Community Groups in the Southern District of Londrina]. São Paulo (BR); 1999. [Dissertação de Mestrado - Faculdade de Saúde Pública da Universidade de São Paulo].

This study was developed from the interest in understanding the relationship between the UNI Project: a New Iniciative in Health Professionals' Education: Community Based and the Health Community Groups related to it. It is a case study about the southern district of Londrina, a city in Paraná State. Using qualitative approachs, the author analyzed documents, individual and colective semi-structured interviews, as well as ethnographic information gathered in the field observation. The results were presented and discussed though seven analitycal categories: articulation, autonomy, organization, partnership, political culture, opposition and participation. The final considerations showed an extremaly positive impact of the Project on these Community Groups during the last eight years. The community has become more participative in the defense of their rights, especially regarding the local public health system. 


\section{ÍNDICE}

1. Apresentação 09

2. A Proposta UNI: Surgimento e Conjuntura 12

3. Movimentos Populares de Saúde no Brasil 18

4. Caracterização do Município de Londrina 37

$\begin{array}{lll}\text { 4.1. Perfil Epidemiológico } & 38\end{array}$

4.2. Breve Histórico dos Serviços de Saúde 41

5. Objetivos 45

5.1. Objetivos Específicos 45

6. Metodologia 46

6.1. Técnicas de Coleta de Dados 47

$\begin{array}{lll}\text { 6.2. Amostra } & 48\end{array}$

6.3. Registro das Informações 49

6.4. Análise dos Resultados 49

6.5. Categorias Analíticas $\quad 50$

7. Resultados e Discussões 54

7.1. Um Movimento Articulado 55

7.2. Um Movimento Lutando por Autonomia 60

$\begin{array}{ll}\text { 7.3. Luta Organizada } & 64\end{array}$

7.4. Quem Ganha com a Parceria ?

7.5. Cultura Política: Construindo um Pacto Popular 81

7.5.1. Relações Políticas $\quad 81$

7.5.2. Práticas Políticas $\quad 86$ 
7.6. Grupos de Oposição: A Luta Pelo Controle Social

96

7.7. Participação

98

$\begin{array}{lll}\text { 8. Considerações Finais } & 101\end{array}$

$\begin{array}{lll}\text { 8.1. Da Metodologia } & 101\end{array}$

8.2. Dos Resultados 101

8.3. Dos Desafios Futuros 107

9. Referências Bibliográficas 109

Anexos 


\section{SIGLAS UTILIZADAS}

\begin{tabular}{|c|c|}
\hline $\begin{array}{l}\text { ABRASCO } \\
\text { AIS }\end{array}$ & $\begin{array}{l}\text { Associação Brasileira de Pós-Graduação em Saúde Coletiva } \\
\text { Ações Integradas de Saúde }\end{array}$ \\
\hline $\begin{array}{l}\text { AIS } \\
\text { ANAMPOS }\end{array}$ & $\begin{array}{l}\text { Açoes Integradas de Saude } \\
\text { Associação Nacional de Movimentos Populares }\end{array}$ \\
\hline APS & Atenção Primária à Saúde \\
\hline ARESCOM & Associação Recreativa, Esportiva e Social do São Lourenço \\
\hline ASMS & Autarquia dos Serviços Municipais de Saúde \\
\hline BID & Banco Interamericano de Desenvolvimento \\
\hline CAIC & Centro de Atendimento Integrado à Criança e ao Adolescente \\
\hline $\operatorname{ccs}$ & Centro de Ciências da Saúde \\
\hline CEB'S & Comunidades Eclesiais de Base \\
\hline CEBES & Centro Brasileiro de Estudos de Saúde \\
\hline CF & Constituição Federal \\
\hline CGT & Central Geral dos Trabalhadores \\
\hline CIGO & Comissão Interinstitucional Gestora e Operativa do PROUNI \\
\hline CLS & Conselho Local de Saúde \\
\hline $\mathrm{CMI}$ & Coeficiente de Mortalidade Infantil \\
\hline CMS & Conselho Municipal de Saúde \\
\hline CNDM & Conselho Nacional dos Direitos da Mulher \\
\hline CNRS & Comissão Nacional de Reforma Sanitária \\
\hline $8^{\mathrm{a}} \mathrm{CNS}$ & $8^{a}$ Conferência Nacional de Saúde \\
\hline CONAM & Confederação Nacional das Associações de Moradores \\
\hline CONCLAT & Confederação Nacional da Classe Trabalhadora \\
\hline CONSCENTRO & Conselho de Saúde da Região Centro \\
\hline CONSLESTE & Conselho de Saúde da Região Leste \\
\hline CONSNORTE & Conselho de Saúde da Região Norte \\
\hline CONSOESTE & Conselho de Saúde da Região Oeste \\
\hline CONSUL & Conselho de Saúde da Região Sul \\
\hline CONTAG & Confederação Nacional dos Trabalhadores da Agricultura \\
\hline CRESUL & Conselho Regional de Educação da Região Sul de Londrina \\
\hline CUT & Central Única dos Trabalhadores \\
\hline ERP & Estimativa Rápida Participativa \\
\hline FAMERJ & Federação das Associações de Moradores do Estado do RJ \\
\hline FWKK & Fundação W. K. Kellogg \\
\hline GERUS & Curso de Gerentes de Unidades Básicas de Saúde \\
\hline IBGE & Instituto Brasileiro de Geografia Estatística \\
\hline IDA & Integração Docente Assistencial \\
\hline IPPUL & Instituto de Pesquisa e Planejamento Urbano de Londrina \\
\hline LOS & Lei Orgânica da Saúde \\
\hline MDB & Movimento Democrático Brasileiro \\
\hline MISC & Departamento Materno Infantil e de Saúde Comunitária \\
\hline MOPS & Movimento Popular de Saúde \\
\hline MST & Movimento dos Sem Terra \\
\hline NAPS & Núcleo de Apoio Psicossocial \\
\hline NESCO & Núcleo de Estudos em Saúde Coletiva \\
\hline NIM & Núcleo de Informação em Mortalidade \\
\hline NOB $1 / 93$ & Norma Operacional Básica 001 de 1993 \\
\hline OMS & Organização Mundial da Saúde \\
\hline
\end{tabular}




$\begin{array}{ll}\text { PCB } & \text { Partido Comunista Brasileiro } \\ \text { PC do B } & \text { Partido Comunista do Brasil } \\ \text { PDT } & \text { Partido Democrático Trabalhista } \\ \text { PEEPIN } & \text { Projeto Especial de Ensino: Práticas Multiprofissionais e } \\ & \text { Interdisciplinares } \\ \text { PES } & \text { Planejamento Estratégico Situacional } \\ \text { PIASS } & \text { Programa Interiorização de Ações de Saúde e Saneamento do NE } \\ \text { PIB } & \text { Produto Interno Bruto } \\ \text { PID } & \text { Programa de Internação Domiciliar } \\ \text { PML } & \text { Prefeitura do Município de Londrina } \\ \text { PPS } & \text { Partido Popular Socialista } \\ \text { PREV-SAÚDE } & \text { Programa Nacional de Serviços Básicos de Saúde } \\ \text { PROAHSA } & \text { Programa de Estudos Avançados em Administração Hospitalar e de } \\ & \text { Sistemas de Saúde do Hospital das Clínicas da Faculdade de } \\ & \text { Medicina da USP e da Escola de Administração de Empresas de } \\ \text { PROCAF } & \text { São Paulo da Fundação Getúlio Vargas } \\ \text { PROUNI } & \text { Programa Comunitário de Atenção Familiar } \\ \text { PSF } & \text { Projeto UNI } \\ \text { PSB } & \text { Programa de Saúde da Família } \\ \text { PT } & \text { Partido Socialista Brasileiro } \\ \text { SES/PR } & \text { Partido dos Trabalhadores } \\ \text { SINASC } & \text { Secretaria do Estado da Saúde do Paraná } \\ \text { SISCAT } & \text { Sistema de Informações sobre Nascidos Vivos } \\ \text { SISVAN } & \text { Sistema de Informações sobre Acidentes de Trabalho } \\ \text { SUS } & \text { Sistema de Informações sobre Vigilância Alimentar e Nutricional } \\ \text { UBS } & \text { Sistema Único de Saúde } \\ \text { UEL } & \text { Unidade Básica de Saúde } \\ & \text { Universidade Estadual de Londrina }\end{array}$




\section{APRESENTAÇÃO}

A elaboração do presente trabalho foi motivada pelo interesse em melhor compreender a relação do Projeto UNI Londrina com os movimentos populares de saúde na região sul do município. Partiu-se da hipótese de que, dentre as conquistas obtidas pelos Projetos UNI em toda América Latina, as que têm se manifestado de forma mais significativa estão relacionadas à comunidade. Tal inferência decorre de experiências anteriormente vividas pelo pesquisador, bem como da observação sistemática das discussões sobre participação popular e movimentos sociais no campo da saúde pública.

Este estudo está estruturado de forma que o capítulo 2 trata de contextualizar o surgimento e a conjuntura dos Projetos UNI: Uma Nova Iniciativa na Formação de Profissionais de Saúde: União com a Comunidade no Brasil, bem como descrever parte dos já reconhecidos avanços da comunidade nos diversos projetos. Retomando autores que discorrem a respeito do tema, procura-se mostrar o processo de reconstrução do ideário UNI, neste final de década, vencidos alguns dos desafios iniciais dos projetos e alteradas as condições sócio-econômicas e políticas em que se desenvolvem as experiências.

No capítulo 3, o objetivo é proporcionar uma compreensão global a respeito dos principais eventos históricos e considerações teóricas relacionadas aos movimentos populares de saúde no Brasil. Esta reconstrução levou à opção por uma definição de movimentos sociais, cujas dimensões possam abrigar os movimentos populares de saúde, bem como entendê-los em relação ao processo da reforma sanitária brasileira.

Trata ainda de inserir no debate conceitos fundamentais de participação popular nos serviços de saúde, com base em autores que têm dedicado suas análises aos conselhos $\mathrm{e}$ as conferências de saúde como instrumentos elementares à implantação e implementação do Sistema Único de Saúde no Brasil. 
Algumas informações fundamentais para a melhor compreensão e localização nos cenários técnico e político estão disponíveis no capítulo 4. Além de descrever alguns indicadores de saúde relacionados tanto ao município como um todo quanto à região em estudo, são descritos também eventos que procuram mostrar a posição de vanguarda que Londrina ocupou na organização dos serviços de saúde, desde a década de 70 até anos mais recentes.

Uma vez apresentado, no capítulo 5, o objetivo geral do trabalho: analisar o papel do PROUNI Londrina na organização dos movimentos populares de saúde na região sul do município de Londrina, bem como os objetivos específicos, as opções metodológicas são descritas no capítulo 6. A apresentação de argumentos que sustentam a escolha por um estudo de caso é seguida de uma descrição dos métodos e técnicas utilizados e da conceituação das categorias analíticas utilizadas: articulação, autonomia, organização, parceria, cultura política, oposição e participação.

Os resultados obtidos em campo estão discutidos no capítulo 7 , onde se delineiam de forma mais clara as informações que sustentam as respostas aos objetivos estabelecidos para o trabalho. De um ponto de vista sistêmico, nas discussões e resultados, estão estabelecidos os caminhos utilizados para a compreensão dos movimentos populares de saúde em Londrina, bem como sua relação com os atuais desafios vividos pelo sistema de saúde brasileiro.

Tendo em vista as dificuldades de implementação do SUS, tanto em virtude da opção macroeconômica do País quanto dos obstáculos políticos estabelecidos nas três esferas de governo, tem-se evidenciado cada vez mais a necessidade de a sociedade civil discutir as alternativas e instrumentalizar-se, de forma a retomar, através da participação, a direção do SUS pelas vias democráticas.

Ainda são muitas as incertezas sobre o papel que caberá aos movimentos sociais, diante da efêmera hegemonia de um modelo econômico que, há muito tempo, já não tem sido suficiente para responder às necessidades da população. Suas conseqüências são conhecidas: empobrecimento e miséria, desemprego, 
tráfico de drogas, violência urbana e rural, fome, trabalho infantil e perfis de morbidade e de mortalidade assustadores. Os velhos desafios renovam-se nos novos atores. Este trabalho pretende apenas contribuir para essas discussões. 


\section{A PROPOSTA UNI: SURGIMENTO E CONJUNTURA}

Desde a década de 40, a atuação da FWKK na América Latina tem se apoiado nas duas principais idéias de sua filosofia organizacional: "aplicar os recursos para resolver os problemas das pessoas" e "ajudar as pessoas a ajudarem a si mesmas" (CHAVES e KISIL 1994). Segundo estes autores, a complexidade política, econômica e cultural dos países latino-americanos tem desafiado a Fundação, ao longo dos anos, a promover e apoiar projetos que efetivamente colaborem para melhor compreender esse processo.

Idéias, indivíduos e instituições têm sido os agentes sociais apoiados pela Fundação. Por isso, a pertinência, a exeqüibilidade, a oportunidade e aplicação das idéias; a responsabilidade e liderança dos indivíduos e a perspectiva de institucionalização de mudanças na região são os principais componentes na formulação de programas tais como o UNI: Uma Nova Iniciativa na Educação dos Profissionais de Saúde: União com a Comunidade.

Segundo CHAVES e KISIL (1994), o objetivo geral da programação da FWKK para o setor saúde é contribuir para que a sociedade conquiste um sistema coordenado, eficiente e eficaz, integrado e integral, e universal. Para alcançá-lo, a Fundação tem lançado mão de instrumentos políticos e gerenciais estratégicos, utilizados, segundo os autores, para vencer os obstáculos impostos aos modelos de desenvolvimento de SILOS, bem como aos modelos de formação de recursos humanos em saúde, entre outros.

Com tais características, vários projetos receberam apoio da Fundação nas últimas décadas, podendo se destacar aqueles produzidos nos Departamentos de Medicina Preventiva, Social e Comunitária nos anos 60 e 70, as mudanças nas escolas de odontologia através do Programa Inovações no final dos anos 70 e, por fim, as experiências mais recentes como o PROAHSA e os programas IDA e UNI (CHAVES e KISIL 1994). 
Em 1987, ao avaliar esse conjunto de experiências, a FWKK destacou dois pontos específicos que exigiriam maior reflexão ao prepararem-se as estratégias de apoio para a década de noventa:

1. a necessidade de reformulação da articulação entre ensino e serviços de saúde, compreendendo a incorporação da multiprofissionalidade;

2. a fragilidade da participação da comunidade na articulação entre ensino e serviços de saúde.

Considerando essas questões, em 1990, a FWKK deu início a um novo programa que pudesse proporcionar maior integração entre ensino, serviços de saúde e comunidade: o Programa UNI. Segundo CHAVES e KISIL (1994) os principais propósitos estabelecidos para o Programa UNI foram:

a) estimular e apoiar os projetos de progresso sincrônico na educação dos profissionais de saúde, na prestação de serviços de saúde e na comunidade, estreitando o relacionamento entre esses três componentes;

b) criar modelos passíveis de replicação referentes a esses três campos, compartilhando, através de um mecanismo de rede, os projetos que o compusessem;

c) criar mecanismos de apoio aos projetos, desde sua formulação, incluída sua avaliação contínua e disseminação de experiências e resultados (CHAVES e KISIL 1994, p. 3).

Em janeiro de 1991, cerca de novecentas escolas de Medicina, Enfermagem, Odontologia, Saúde Pública e Administração em Saúde da América Latina receberam uma carta convite para participar do Programa UNI. Dentre essas escolas, figurava o Centro de Ciências da Saúde da Universidade Estadual de Londrina'. Em julho de 1992, a FWKK anunciava publicamente as quinze

\footnotetext{
${ }^{1}$ Os cursos de graduação do CCS/UEL são Enfermagem, Farmácia, Fisioterapia, Medicina e Odontologia.
} 
propostas aprovadas que tiveram sua fase de implementação iniciada em outubro desse mesmo ano ${ }^{2}$.

Segundo FEUERWERKER e SENA (1999), os Projetos UNI são iniciativas de grande complexidade, tendo em vista duas situações particulares. Em primeiro lugar, deve-se considerar que os projetos, tanto no Brasil quanto nos países vizinhos, foram construídos em conjunturas políticas e sociais ainda marcadas por recentes regimes militares, cuja herança autoritário-burocrática ainda se apresenta de maneira expressiva na sociedade.

Em segundo lugar, é preciso levar em conta a conjuntura social e econômica dos países da região que atravessam crises político-econômicas de grande amplitude, provocando o empobrecimento vertiginoso do continente. É nesse cenário que foram construídas as relações de parceria entre Universidade, Serviços de Saúde e Comunidade, onde está freqüentemente presente um processo contraditório de construção e desconstrução da cidadania.

Embora a Universidade tenha por definição um papel mentor na articulação entre os três componentes dos projetos UNI, conferindo a eles um caráter nitidamente acadêmico, mudanças concretas foram sendo operadas em seu dia-adia e um novo e amplo ideário foi construído pelos componentes dos projetos (FEUERWERKER e SENA 1999).

Em meio à reconhecida ampliação dos projetos, a comunidade surgiu como parte essencial das mudanças, sendo que em algumas das experiências particulares foi o componente que mais se desenvolveu. Se ao iniciar-se o UNI, as metas para a comunidade eram propiciar modelos de participação comunitária nas decisões relativas ao setor saúde, modelos de trabalho em comunidade por meio de equipes multiprofissionais e novos líderes na área de saúde (CHAVES e KISIL 1994), depois de quase 8 anos de trabalho, as conquistas observadas em alguns projetos são ainda maiores.

\footnotetext{
${ }^{2}$ Ver no Anexo 1 relação dos Projetos UNI na América Latina.
} 
A partir da superação das expectativas iniciais, FEUERWERKER (1998) afirma que os projetos transformaram-se em projetos de desenvolvimento social pela observação de ao menos cinco pontos diferentes:

a) apropriação de conhecimentos pela comunidade;

b) ocupação de espaços antes restritos a grupos políticos distintos do movimento comunitário;

c) possibilidade de reflexão e definição das necessidades e prioridades pela própria comunidade;

d) conquista pelas organizações comunitárias de novos interlocutores na sociedade local;

e) ruptura das barreiras da alternância de poder na universidade, nos serviços e nos governos locais através das atividades dos projetos (FEUERWERKER 1998, p. 2-3).

Segundo CHAVES e KISIL (1994), quatro premissas fundamentam o apoio aos projetos UNI. São elas o protagonismo ativo dos grupos, o gradualismo dos processos, o paralelismo e simultaneidade das ações e o apoio técnico interdisciplinar. Para o componente comunidade, tem grande importância o protagonismo ativo, à medida que exige o reconhecimento pleno e cabal de que o grupo é o sujeito do processo de desenvolvimento, ou seja, que a comunidade conduz as mudanças, segundo sua própria visão da realidade e suas expectativas e percepções quanto à construção de um caminho para superar as situações de dificuldade.

Reforça essa idéia a orientação explicita da FWKK para que nos projetos haja uma integração dos parceiros voltada ao compartilhamento do UNI em toda sua dinâmica. FEUERWERKER (1998) afirma que essa orientação favoreceu a redistribuição de poder e a democratização das relações entre os parceiros, desencadeando processos de mudanças que em alguns aspectos superaram as expectativas originais do programa. 
No caso da comunidade, três vertentes impulsionadas pelo compartilhamento no UNI merecem maior destaque. A primeira delas é o que IZQUIERDO (1994) denomina de enfoque comunitário no modelo de serviços de saúde e que, posteriormente, ganhou maior amplitude com as análises de controle social dos serviços de saúde realizadas por FEUERWERKER e SENA (1999).

Segundo as autoras, houve um investimento importante na criação e fortalecimento de conselhos de saúde e na implantação de métodos de planejamento participativo nas UBS envolvidas nos projetos, o que impulsionou o processo de mudança. A capacitação de conselheiros de saúde e a disseminação de informações em saúde para a população foram instrumentos que também trouxeram um positivo impacto social.

A segunda vertente diz respeito ao que é denominado por IZQUIERDO (1994) como implicações do enfoque comunitário no modelo acadêmico. Segundo o autor, os eixos de compromisso que dariam direção a essa mudança estariam apoiados na reestruturação curricular e pedagógica, a fim de aumentar a integração entre ensino e comunidade.

Sobre o tema, FEUERWERKER e SENA (1999) afirmam que seria indispensável ao processo de mudança a adoção de concepções pedagógicas críticas, reflexivas e problematizadoras, bem como de metodologias de ensino que permitissem a participação ativa dos estudantes em diferentes e novos cenários de ensino. Como exemplo de espaços comunitários: os domicílios, as escolas, as igrejas, as associações de moradores, etc.

De acordo com as autoras, a participação dos atores dos serviços de saúde e da comunidade proporcionaram a interação dos componentes UNI em um espaço plural de interesses, potencialidades e capacidades. Essa interação significou na prática a definição de novos conteúdos e a orientação dos trabalhos dos estudantes, para que novas práticas surgissem no espaço acadêmico, não mais como objeto exclusivo de departamentos (FEUERWERKER e SENA 1999). 
A terceira vertente, tratada inicialmente por IZQUIERDO (1994) como significação do programa UNI para a própria comunidade, ganhou maior amplitude com as análises sobre a construção da cidadania elaboradas por FEUERWERKER e SENA (1999).

Em princípio, cabe ressaltar que a construção da cidadania tornou-se mais visível a partir da significativa democratização das relações entre universidade, serviços de saúde e comunidade. Nesse processo, as autoras identificam três elementos que parecem estar dinamicamente relacionados nos projetos: 1) criação de espaços de interlocução entre os parceiros; 2) a democratização da informação e o "diálogo entre saberes"3, instrumentos fundamentais para a redistribuição do poder e para o "empoderamento" ${ }^{4}$ dentro dos projetos; 3) apropriação de conhecimentos pela comunidade.

Assim, o desenvolvimento do componente comunidade nos projetos parece ser um de seus mais expressivos resultados, representando importantes mudanças políticas e sociais. Em alguns momentos, ainda segundo FEUERWERKER e SENA (1999), o UNI proporcionou à comunidade espaços reais para a resolução dos problemas e construção de projetos coletivos, bem como poder para interferir em sua realidade social e econômica.

\footnotetext{
${ }^{3}$ Aspas das autoras.

${ }^{4}$ Termo originado da tradução do inglês empowerment.
} 


\section{MOVIMENTOS POPULARES DE SAÚDE NO BRASIL}

O surgimento e o fortalecimento dos movimentos populares de saúde no Brasil estão vinculados ao momento histórico em que despontaram na sociedade os novos movimentos sociais. No período compreendido entre os anos de 1978 e 1989, denominado por GOHN (1997) de "era da participação", ganharam expressão no cenário político nacional, o movimento pela anistia (1977 - 1978), o ciclo de greves (1978 - 1979), o movimento nacional contra a carestia (1974 1980), o movimento feminista (1975 - 1982), a mobilização nacional contra o regime militar (1978 - 1984), os movimentos de base eclesial como as CEB's e a organização de movimentos ecológicos, étnicos e por direitos humanos.

Os movimentos populares por saúde e saneamento, bem como 0 movimento pela reforma sanitária, que teve sua pedra fundamental com a criação do CEBES $^{5}$ em 1976, também tornaram-se expressivos na década de setenta. Além desses, a criação da CONAM em 1982, da ANAMPOS em 1983, da CGT e da CUT em 1982 e 1983 respectivamente, compõem o cenário inicial das lutas urbanas brasileiras.

Foram esses movimentos que inauguraram no Brasil o conceito de novos movimentos sociais. Por terem surgido em uma sociedade marcada por relações clientelistas e autoritárias, em um Estado totalitário-burocrático e juridicamente inoperante (GOHN 1997), a agenda e as práticas desses movimentos romperam a demanda apenas por bens e serviços necessários à sobrevivência, para incorporarem a luta por direitos sociais modernos como igualdade e liberdade, bem como pela construção de uma sociedade melhor, através de vias democráticas.

\footnotetext{
${ }^{5}$ Existe discordância entre diferentes autores a respeito da existência ou não de uma pedra fundamental do movimento pela reforma sanitária no Brasil. A opção aqui adotada procura entender no contorno institucional adotado pelo movimento, a sua origem. Nesse sentido, a criação do CEBES em 1976 é reconhecidamente o ponto inicial. Sobre o assunto, consultar ESCOREL (1998), FLEURY (1997), CARVALHO (1995), NETO (1997).
} 
Segundo FLEURY (1997), a proposta democrática pela qual se lutava na década de setenta possuía um forte conteúdo contra-cultural. A democracia traduzia-se na desalienação e organização da população em direção à apropriação de sua riqueza e o mecanismo que permitiria essa transição seria a participação popular, através da qual se criaria uma nova lógica de ordenação do poder.

O conflito seria, pois, o caminho através do qual se poderia desmontar as estruturas de dominação, ao mesmo tempo que, ao assim proceder, se estaria produzindo a desalienação do sujeito que se constitui por meio de sua participação (FLEURY 1997, p. 27).

Os novos movimentos sociais assumiram dupla importância no questionamento do regime político então vigente. Em primeiro lugar, porque possuíam boa parte de seus quadros compostos por ativistas até então marginalizados da vida social e política, o que garantia a ampliação dos debates conduzidos pelos movimentos (HELLMANN 1995). Ampliação que thes conferia a ruptura com sua origem estritamente vinculada às contradições capitalistas, aos problemas urbanos emergenciais e às demais carências da sociedade. A presença desses ativistas deu-se essencialmente a partir do bloqueio institucional criado pelo regime sobre as formas de organização tradicionais, como os sindicatos, o movimento estudantil e os partidos políticos (HELLMANN 1995).

Em segundo lugar, porque os movimentos desenvolveram novas formas de luta em diversos setores da sociedade, principalmente a partir da transferência dos debates do campo da produção, identificados e perseguidos pelo regime, para o campo da reprodução da força de trabalho, o que envolvia as condições de vida do trabalhador nos cenários urbanos.

De acordo com ZIONI (1994), citando Cardoso [sd], a teoria européia das contradições urbanas teve influência marcante no pensamento sociológico brasileiro. A autora afirma que os movimentos sociais eram definidos como lutas 
urbanas que expressavam a luta de classes no mundo capitalista contemporâneo, associando à problemática urbana contradições do mundo da produção.

No período entre 1968 e 1973, o milagre brasileiro, embora responsável por um forte crescimento do PIB nacional ${ }^{6}$, produziu grandes desigualdade sociais. A extrema concentração de renda e a favelização das massas operárias são suas expressões mais visíveis. A desenfreada urbanização condicionou o surgimento de grandes bolsões de miséria na periferia dos grandes centros urbanos, como em São Paulo, Rio de Janeiro, Recife, Salvador, Porto Alegre, Brasília e Belo Horizonte.

Assim, a massa trabalhadora era duplamente penalizada pelo regime militar que, por um lado, incentivava a exploração desmedida da força de trabalho, fato observado a partir da concentração de renda e, por outro, isentava-se de criar as condições adequadas de transporte, moradia, educação e, principalmente, saúde. Essa crise não tardou em sair dos limites de controle do regime. A falência do milagre brasileiro, quer influenciada pela crise mundial do petróleo, quer pela conformação do próprio regime, obrigou-o a iniciar a política da distensão, a partir de $1974^{7}$.

Ao refletir sobre a origem dos novos movimentos sociais e, dentre eles, os movimentos populares de saúde, existe, segundo ZIONI (1994), um certo consenso teórico quanto à emergência dos movimentos no contexto da crise de legitimidade do regime.

Essa crise que se mostra do ponto de vista do governo, pelas oscilações entre uma política de liberalização (distensão lenta e gradual) e outra de manutenção da ordem, além de apontar para a necessidade de desenvolvimento de políticas públicas que

\footnotetext{
${ }^{6}$ Ver, no Anexo 2, tabela contendo a evolução do PIB Nacional entre os anos de 1960 a 1999.

7 O processo de "abertura" é objeto de divergência entre os pesquisadores que discutem suas origens. Seria resultado da crise econômica, da busca de institucionalização e legitimidade para o regime militar autoritário, de problemas no interior da corporação militar resultantes do prolongado exercício do poder político e/ou de uma crise jurídico-institucional do País sob o governo militar? (ESCOREL 1998).
} 
legitimem o governo em crise, abre espaço para a manifestação da sociedade civil (ZIONI 1994, p. 38).

Antes, porém, de prosseguir nas discussões sobre a origem e crescimento dos movimentos populares de saúde, é preciso estabelecer algumas condições teóricas para a sua compreensão. Segundo GOHN (1997), existem cinco formas possíveis de expressão dos movimentos sociais:

a) Movimentos construídos a partir da origem social da instituição que apoia ou abriga seus demandatários.

b) Movimentos sociais construídos a partir das características da natureza humana: sexo, idade, raça e cor.

c) Movimentos sociais construídos a partir de determinados problemas sociais.

d) Movimentos sociais construídos em função de questões das conjunturas políticas de uma nação (sócio-econômica, cultural, etc.).

e) Movimentos sociais construídos a partir de ideologias (GOHN 1997, p. 268-71).

Para a autora, os movimentos populares de saúde seriam construídos a partir de determinados problemas sociais, situando-se na seguinte discussão:

Todo coletivo enfrenta dificuldades a serem superadas na sobrevivência cotidiana. Independente da classe social de um indivíduo, ele precisa ter acesso a condições de abrigo, alimentação etc. Várias dessas condições só são possíveis à maioria da população no nível do coletivo. São os chamados equipamentos coletivos de consumo: escola, saúde, transportes, lazer etc. (GOHN 1997, p. 269).

Para melhor compreensão dessa classificação, é preciso explicitar o conceito de movimentos sociais que acompanha este trabalho. A análise de algumas das categorias teóricas presentes nessa definição torna mais clara a 
relação entre os movimentos populares de saúde e os atores interna e externamente a eles relacionados.

Movimentos sociais são ações sócio-políticas construídas por atores sociais coletivos pertencentes a diferentes classes e camadas sociais, articuladas em certos cenários da conjuntura sócioeconômica e política de um país, criando um campo político de força social na sociedade civil. As ações se estruturam a partir de repertórios criados sobre temas e problemas em conflitos, litígios e disputas vivenciadas pelo grupo da sociedade. As ações desenvolvem um processo social e político cultural que cria uma identidade coletiva para o movimento, a partir dos interesses em comum. Esta identidade é amalgamada pela força do princípio da solidariedade e construída a partir da base referencial de valores culturais e políticos compartilhados pelo grupo, em espaços coletivos não institucionalizados. Os movimentos geram uma série de inovações nas esferas públicas (estatal e não estatal) e privada; participam direta ou indiretamente da luta política de um país, e contribuem para o desenvolvimento e a transformação da sociedade civil e política. Estas contribuições são observadas quando se realizam análises de períodos de média ou longa duração histórica, nos quais se observam os ciclos de protestos delineados. Os movimentos participam portanto da mudança social histórica de um país e o caráter das transformações geradas poderá ser tanto progressista como conservador ou reacionário, dependendo das forças sociopolíticas a que estão articulados, em suas densas redes; e dos projetos políticos que constróem em suas ações. Eles têm como base de suporte entidades e organizações da sociedade civil e política, com agendas de atuação construídas ao redor de demandas socioeconômicas ou político-culturais que abrangem as problemáticas conflituosas da sociedade onde atuam (GOHN 1997, p. 251).

Considerando tais análises, é necessário diferenciar ao menos três formas distintas de organização dos movimentos de saúde: 1) os diversos movimentos 
populares de saúde que não ultrapassam o campo das reivindicações; 2) os movimentos populares de saúde que, considerada a definição de GOHN (1997), assumem um perfil de movimento social; 3) um movimento sanitário que aglutina boa parte das demandas dos movimentos populares, articulando-as às agendas dos movimentos acadêmicos, dos movimentos de profissionais, de alguns partidos políticos, entre outros, e que provoca as transformações em curso no sistema de saúde brasileiro.

Analisando esse movimento, a partir da colocação de Touraine (1986) citado por ZIONI (1994), chegar-se-ia a definição de que alguns desses movimentos não teriam se organizado apenas como forma de expressão de uma contradição ou de resolução de um determinado problema, mas teriam sido, em muitas oportunidades, o próprio elemento gerador ou detonador de um determinado conflito. Há, portanto, duas análises distintas - em certo grau complementares - a serem realizadas. A primeira diz respeito aos movimentos populares de saúde e a segunda ao movimento sanitário brasileiro.

Ao se analisar o início da articulação dos movimentos populares de saúde na década de 70, identifica-se em vários autores (BÓGUS 1998, CARVALHO 1995, ESCOREL 1998, HELLMANN 1995, ZIONI 1994) praticamente um consenso sobre os agentes externos que contribuíram para sua articulação, organização e discussão política: a Igreja católica; o movimento de mulheres, o movimento sindical, os movimentos de bairros por moradia e saneamento, os médicos sanitaristas e, por fim, os grupos e partidos políticos na clandestinidade.

A Igreja católica, que através das CEB's difundia princípios da Teologia da Libertação, desempenhou um papel essencial ao levar um número crescente de moradores das periferias dos grandes centros urbanos a se organizarem em torno da discussão e da resolução de seus problemas cotidianos $^{8}$ (ESCOREL 1998). Esses foram os espaços abertos para que as diversas lutas em andamento pudessem ser vistas de forma conjunta, permitindo aos movimentos populares,

\footnotetext{
${ }^{8}$ É preciso ressaltar que as CEB's foram apenas uma das frentes de luta conduzidas pela Igreja,
} principalmente nos anos de governo do presidente Ernesto Geisel (1974 a 1979): 
ainda que de maneira tênue, organizar e ampliar suas concepções de uma agenda de luta por melhores condições de saúde. Segundo ZIONI (1994), o fechamento dos canais institucionais de participação transformaram a Igreja Católica em uma das poucas instituições civis capazes de articular certo nível de oposição.

O movimento de mulheres, que também ganhava estrutura e organicidade na segunda metade da década de 70 , iluminou novos campos de conflito social, aparecendo como um novo ator. Conforme DELGADO e SOARES (1995), as mulheres organizaram-se e transcenderam seu cotidiano doméstico de anulação e silêncio para surgirem como grupos reivindicativos importantes, organizados principalmente em torno das ações de subsistência familiar. Ainda conforme as autoras, com a consolidação desses movimentos de origem familiar-comunitária, as mulheres constituíram a espinha dorsal de muitas das organizações da sociedade civil e dos partidos de oposição no Brasil.

No movimento de saúde, o papel das mulheres, não só através do Clube de Mães (....) também representa uma quebra com os padrões tradicionais de vivência na esfera do privado. A partir de seu envolvimento com os problemas do bairro e suas carências, a participação das mulheres contribui para o rompimento do isolamento em que estas se situam tradicionalmente na qualidade de donas de casa. Ao se instalar, de certa forma, uma prática de reflexão coletiva, estas se transformam nas verdadeiras articuladoras deste e de outros movimentos (JACOBI 1989, p. 28).

O novo sindicalismo, surgido no final da década de 70 , traria para a agenda de lutas das massas assalariadas a reivindicação por reposições das grandes perdas salariais ocorridas entre os anos 60 e $70^{\circ}$. Através das comissões de saúde dos bairros, das reuniões de Igrejas ou mesmo da imprensa clandestina, a temática salarial também se somava às discussões sobre qualidade de vida e saúde. Com o apoio dos movimentos populares da época, as primeiras mobilizações nos contextos de grandes empresas, com destaque para o pólo 
industrial do $A B C$ paulista, ocorreram a partir de meados da década de 70 (CASTRO 1995).

Outra temática que esteve relacionada com os movimentos populares de saúde da década de 70 foi a luta por moradia e saneamento básico, principalmente nas grandes cidades como São Paulo e Rio de Janeiro. Novamente as discussões sobre as dimensões envolvidas com o processo saúdedoença apareciam relacionadas às reivindicações mais concretas das camadas populares, no caso, habitação e saneamento.

Ao analisar as articulações entre os movimentos por saneamento básico e saúde e o poder público na cidade de São Paulo, JACOBI (1989) chama atenção para o amplo espectro coberto pelas ações dos movimentos. No caso da luta pela água, o autor retrata um dos momentos vividos na época:

O fornecimento de água potável se constitui em necessidade impostergável num momento em que parcela significativa da população da periferia tem seu lençol freático contaminado, obrigando-a a consumir água comprovadamente poluída, com um aumento significativo dos níveis de mortalidade infantil (JACOBI 1989, p. 23).

Outros atores que exerceram importância fundamental na organização e articulação dos movimentos populares de saúde na década de 70 foram os médicos sanitaristas. Segundo SMEKE (1990), há experiências registradas em São Paulo, no Vale do Ribeira, em Campinas, Londrina, no interior da Bahia e de Minas Gerais, Pernambuco e Goiás.

Para MERHY (1987), após a intensa repressão ao movimento popular no pós-64, a partir dos anos 70, começaram a florescer experiências embrionárias de contato entre profissionais de saúde e as camadas populares. Segundo o autor, o ideal comum a esses profissionais era:

${ }^{9}$ Durante o período de 1967 a 1975 , os salários reais tiveram perda média anual de $9,5 \%$ (CASTRO 1995). 
Atuar junto ao povo para que houvesse avanço do grau de consciência e organização das massas populares, para que estas criassem o seu caminho para a libertação (....) um trabalho cujo objetivo era criar um processo politizador, isto é, que levasse a população trabalhadora, pelo aumento de sua consciência da realidade, a lutar pela satisfação de suas necessidades através do confronto com o sistema social no qual vivia (MERHY 1987, p. 45).

De acordo com JACOBI (1989), o trabalho dos sanitaristas possibilitou uma universalização dos conhecimentos técnicos, dando subsídios à população para que melhorasse suas reivindicações. Ainda segundo o autor, os sanitaristas tiveram um papel relevante no aumento da conscientização dos moradores, a partir de sua ação pedagógica. Para BÓGUS (1998), os cursos sobre prevenção e noções básicas de higiene em saúde foram fundamentais nesse processo.

Os grupos e organizações partidárias na clandestinidade também estiveram envolvidos no processo de dar ao debate entre o pretendido Estado democrático e o Estado autoritário-burocrático uma expressão de massa. Isto se deu a partir da condução dessas discussões em meio à crescente teia de articulação formada pelos movimentos populares em todo o País. Para JACOBI (1989), os bairros foram o espaço possível para a sobrevivência dos grupos de esquerda, um dos motivos a explicar sua marcante presença nos movimentos populares de saúde.

Para alguns autores, o próprio Estado faria o papel de mais um agente externo que teria dado suas contribuições ao desenvolvimento dos movimentos populares de saúde no Brasil. Entretanto, optou-se aqui por tomar o Estado a partir de três situações distintas (não excludentes): 1) como o criador de alguns cenários de luta popular, principalmente a partir de políticas econômicas e sociais não realizadas; 2) como protagonista da crise de legitimidade; 3) como aparelho aglutinador de forças de oposição aos movimentos sociais. Dessa forma, as ações do Estado estenderam-se por toda a década de 70 , difundindo-se também no período da transição democrática nos anos 80 . 
A reativação das organizações políticas foi uma das primeiras medidas de abertura tomadas pelo governo Geisel que, proporcionando eleições nos anos de 74, 76 e 78, contribuiu diretamente para o crescimento das articulações e debates na sociedade civil. Apesar da alternância entre políticas de ligeira "abertura democrática" e políticas repressivas - cassação, seqüestros e prisões, fechamento do Congresso Nacional em 77 -, o saldo do período foi considerado por ESCOREL (1998) como politicamente positivo.

No período do governo Figueiredo (1979 - 1984), apresenta-se uma lenta porém significativa abertura democrática, da qual são marcas fundamentais a anistia geral aos exilados políticos e o retorno da liberdade partidária. No quadro político, a fundação do PT em 1980, em conseqüência de diferenças entre os atores da esquerda até então abrigados no MDB, veio representar a incorporação de muitas demandas dos movimentos populares da década de setenta a um partido político.

Com isso, é possível compreender o período entre os anos de 1968 e 1980, como aquele em que os diversos atores envolvidos com as transformações no setor da saúde no Brasil mais se desenvolveram e se integraram. Em seu conjunto, o movimento sanitário saiu política e ideologicamente fortalecido da década de 70 , ganhando forças para marchar rumo às importantes conquistas sanitárias que veio a obter nos anos 80 . Os movimentos populares ganharam uma expressão social inédita ao organizarem suas agendas em torno da luta comum pela conquista da democracia. Um dos eventos de maior expressão nesse caso foi a campanha pelas Diretas Já em 1984.

Antes de prosseguir com maiores reflexões sobre o caminho percorrido pelos movimentos populares a partir de 1985, cabe destacar a reflexão construída a partir das leituras e estudos sobre a reforma sanitária nas décadas de 70 e 80 . Do ponto de vista de boa parte dos autores que discorrem sobre o tema, é tratada de forma muito reduzida, quase inexistente, a relação entre os movimentos populares de saúde e o movimento pela reforma sanitária. 
Isto vem apoiar a diferenciação dos movimentos de saúde realizada anteriormente. Considerando o conceito de movimentos sociais de GOHN (1997) e resgatando as contribuições de Touraine (1986) citadas por ZIONI (1994), é possível identificar um movimento sanitário ainda operante no Brasil, do qual participaram e participam uma infinidade de atores sociais comprometidos com a real implantação do SUS. Dentre esses atores, figuram movimentos populares de saúde, movimentos acadêmicos, partidos políticos, sindicatos e conselhos profissionais, entre outros; e em um período anterior, o movimento pela reforma sanitária.

De maneira complementar, há que se considerar uma importante contribuição de ESCOREL (1998) na análise da relação entre os movimentos populares de saúde e o movimento pela reforma sanitária. Tal observação demonstra concretamente as preocupações dos então intelectuais da reforma sanitária $^{10}$ com as bases populares do movimento, em uma significativa demonstração da inter-relação de ambos no todo do movimento sanitário brasileiro.

O movimento sanitário, em sua conformação, falava de uma classe operária que não aparecia no cenário político nem geral nem setorial. Por ser um movimento e não um partido, e por falar de uma classe ausente, o discurso médico-social de transformação continha esse outro ponto de tensão: sem contar com a participação direta da classe trabalhadora, o discurso e a prática do movimento sanitário era feito para ela (em direção a ela) ou por ela (no lugar dela). O distanciamento concreto entre o movimento e seu objeto fez emergir uma crítica interna questionando a representatividade e a própria legitimidade da existência do movimento sanitário (...). Mas é um movimento coletiva e organicamente ligado às classes populares e à

\footnotetext{
${ }^{10}$ Segundo FLEURY (1997) e ESCOREL (1998), eram três as vertentes principais de atores da reforma sanitária: 1) o grupo responsável pela ampliação da consciência sanitária: o movimento estudantil e o CEBES; 2) o movimento de médicos residentes e de renovação médica, que realizava a atuação concreta no mundo do trabalho, bem como ocupava espaços e definia ações estratégicas de ação política; 3) a academia, a qual foi responsável pela construção de um novo saber relacionando a saúde com as condições da estrutura social.
} 
proposta de melhoria de suas condições de saúde (ESCOREL 1998, p. 182).

O cenário onde se encontram maiores interações entre esses movimentos é aquele onde se formulam e se realizam as reflexões dos atores da reforma sanitária a respeito da participação popular no sistema de saúde pretendido. Entretanto, ao mesmo tempo que as contribuições teóricas são bastante expressivas, vindo inclusive a colaborar na elaboração da proposta de controle social no SUS, a prática da participação popular dentro das experiências de mudança em que atuaram atores comprometidos com a reforma sanitária é bastante modesta.

Dentre essas experiências, possuem destaque as AIS em alguns Estados do País (CARVALHO 1995); a atuação de sanitaristas em algumas secretarias municipais de saúde ${ }^{11}$, influenciadas pelos preceitos da medicina comunitária e pelas recomendações da OMS relativas ao desenvolvimentos da APS, e o PIASS e o PREV-SAÚDE ${ }^{12}$ (CAMPOS 1994).

A partir de 1985, é preciso reconhecer que as ligações orgânicas entre esses movimentos foram de grande importância na articulação em prol das Diretas Já e, logo depois, na preparação para a $8^{a} \mathrm{CNS}$, envolvendo paralelamente quadros de ambos os movimentos ${ }^{13}$.

Apesar da derrota das oposições a partir da manobra conservadora no colégio eleitoral, que elegeu Tancredo Neves para a presidência da república, a Nova República viabilizou a retomada das vias democráticas para o conjunto da sociedade. Já no governo de José Sarney (1985 - 1989), em virtude da morte de Tancredo Neves, o setor saúde abriu espaço para um conjunto de propostas e de quadros técnicos que representaram dentro do aparelho de Estado uma idéia

\footnotetext{
${ }_{11}^{11}$ ESCOREL (1998) chama atenção para as experiências em Niterói, Campinas e Londrina.

12 ESCOREL (1998) denomina as ações deste período (1979/80 - 1982/84) de "sonho tecnocrático.

${ }^{13}$ Não se pode esquecer contudo da opção explícita do movimento pela reforma sanitária, a partir de 1982/83 de ocupar espaços no aparelho de Estado, perdendo muito de sua ligação com os movimentos populares (ESCOREL 1998).
} 
contra-hegemônica à política então vigente. Entre outras coisas, essa ocupação de espaços contribuiu para a convocação e realização da $8^{a}$ CNS (CARVALHO 1995).

Até chegar à $8^{a}$ CNS, conferências em todos os Estados da União promoveram discussões sobre os temas gerais propostos. Dessas discussões participaram centenas de entidades e milhares de representantes da sociedade civil, ampliando o debate e as propostas do movimento sanitário. Em praticamente todos os relatórios das conferências estaduais, afirma-se a participação dos movimentos populares de saúde, CEB's, MOPS, comissões de saúde, sindicatos, movimento de mulheres, movimentos por moradia, entre outros (ANAIS DA $8^{a}$ CNS 1987). É possível também localizar em muitas das conferências estaduais a presença do CEBES e da ABRASCO ${ }^{14}$, atores que aglutinaram e promoveram muitas das reflexões produzidas ao longo das décadas de 70 e 80 .

Durante a primeira mesa redonda da $8^{a}$ CNS, uma fala significativa é apresentada por AROUCA (1987), que a presidia, sendo uma das lideranças mais expressivas da luta pela reforma sanitária:

Gostaria também de pedir licença aos sanitaristas, aos médicos, aos profissionais da área, aos pesquisadores, aos funcionários do Ministério da Saúde, para destacar um convidado especial, um participante que conseguiu um lugar nesta Conferência com bastante sacrifício: a sociedade civil brasileira organizada. (....) Creio ser bastante significativa a presença, na $8^{\text {a }} \mathrm{CNS}$, de representantes de confederações nacionais de trabalhadores, de associações de bairro e outras entidades da sociedade brasileira (AROUCA 1987, p. 35).

É fato que a $8^{\mathrm{a}}$ CNS foi um dos maiores espaços democráticos criados no País, após o fim do regime militar que se estendera por 20 anos. Entre os dias 17 e 21 de março de 1986, mais de 4.000 pessoas participaram dos trabalhos realizados em Brasília. 
Rompendo o caráter eminentemente técnico e a baixíssima representatividade das sete conferências anteriores (CARVALHO 1995), a $8^{\text {a }}$ CNS foi um marco de participação. Além da presença de centenas de entidades populares de base, o papel de conferencista, realizado por algumas entidades populares, ilustra os avanços da participação da sociedade organizada naquele evento, sendo identificados o CONAM, CNDM, CUT, FAMERJ, CONTAG e CONCLAT (ANAIS DA $8^{\text {a }}$ CNS 1987).

Ainda que de forma geral, a $8^{\text {a }}$ CNS possa ser considerada uma vitória para o movimento sanitário, bem como para todos os setores da sociedade que vinham lutando pela ampliação das bases democráticas no país, o fato que isoladamente chama atenção para este trabalho foi a aprovação das propostas de participação da população, através de suas entidades representativas, na formulação da política, no planejamento, na gestão, na execução e na avaliação das ações de saúde, além é claro, do reconhecimento da saúde como direito universal do cidadão (ANAIS DA $8^{a}$ CNS 1987).

Ao final da $8^{\text {a }} \mathrm{CNS}$, intensificaram-se as lutas pró-constituinte. Além da criação da CNRS, responsável pela formulação do projeto de reordenamento do sistema de saúde, ganhou expressão a Plenária Nacional de Entidades de Saúde (PNES), espaço onde atuaram o MOPS, a CONAM, a CUT, a CONTAG, a CGT, além de partidos de esquerda e os tradicionais atores da reforma sanitária, como o CEBES, a ABRASCO, os conselhos e sindicatos profissionais, entre outros (ESCOREL 1998).

A partir do relatório final da $8^{\mathrm{a}} \mathrm{CNS}$ e dos relatórios de trabalho elaborados pela CNRS, a PNES assumiu três papéis importantes em prol do movimento sanitário: 1) aglutinador de forças políticas; 2) articulador das propostas técnicojurídicas; 3) principal interlocutor de oposição aos lobbistas conservadores presentes no Congresso Constituinte (CARVALHO 1995).

\footnotetext{
${ }^{14}$ Esses atores foram identificados nas conferências do RJ, PR, PB e DF.
} 
As propostas elaboradas pela Plenária foram de fato vencedoras. A Constituição Federal de 03 de outubro de 1988 definiu a nova organização do sistema de saúde brasileiro, através da criação do SUS. Para essa análise, chama atenção duas passagens específicas do texto constitucional. Em primeiro lugar, o Artigo 196 e, em segundo, o Artigo 198 que define a participação popular como uma das diretrizes do SUS:

Art. 196. A saúde é direito de todos e dever do Estado, garantido mediante políticas sociais e econômicas que visem à redução do risco de doença e de outros agravos e ao acesso universal e igualitário às ações e serviços para sua promoção, proteção e recuperação.

Art. 198. As ações e serviços públicos de saúde integram uma rede regionalizada e hierarquizada e constituem um sistema único, organizado de acordo com as seguintes diretrizes:

I - descentralização, com direção única em cada esfera de governo;

II - atendimento integral, com prioridade para as atividades preventivas, sem prejuízo dos serviços assistenciais;

III - participação da comunidade (BRASIL 1994, p. 92).

Além disso, no trabalho de construção que adentrou a década de 90 , as articulações do movimento sanitário garantiram a aprovação da Lei 8080 em 19 de setembro de 1990 (LOS), que em seu artigo sétimo reafirmava o artigo 198 da Constituição Federal (BRASIL 1995a). Contudo, o veto do então presidente Fernando Collor (1990 - 1992) ao artigo 11 da LOS, justamente aquele que regulamentava a participação popular nas esferas do SUS (CARVALHO 1995), provocou uma outra batalha que veio a ser vencida pelo movimento sanitário. Em 28 de dezembro de 1990, publicava-se a Lei 8142, que regulamenta o controle social sobre o SUS (BRASIL 1995b). 
Foram criadas assim, nas três esferas de governo, as conferências e os conselhos de saúde, cujas funções são a formulação das políticas de saúde e as estratégias de controle do SUS. No cerne dessas instâncias, aparece o critério da paridade entre governo, prestadores de serviços, profissionais de saúde e usuários. A publicação da NOB 01/93, já no governo Itamar Franco ${ }^{15}$, conferiu ainda maior importância às esferas de participação ao defini-las como critério essencial para a municipalização da saúde.

Ao longo da década de 90, alguns fatores sociopolíticos vieram a inviabilizar, em certa medida, os projetos políticos dos movimentos sociais das décadas de 70 e 80. Para GOHN (1997), a perda de boa parte da capacidade de mobilização e do esforço voluntarista que se observava anteriormente deve-se às seguintes situações: o crescimento das grandes centrais sindicais, a aglutinação dos movimentos populares em grandes confederações, a decepção da sociedade civil com o instável quadro político da Nova República, o surgimento de inúmeros guetos corporativos, as conseqüências advindas da derrota do candidato da esquerda em $1989^{16}$ e o surgimento das ONG's, que viriam a ser quase substitutas dos movimentos sociais na década de 90 .

Deve-se considerar ainda o modelo econômico adotado nos governos Cardoso (1995 - 1998 e 1999 - atual), pano de fundo para muitas das modificações em curso no cenário nacional. Segundo GOHN (1997), há quatro elementos que têm apresentado grande influência no atual quadro.

O primeiro diz respeito à grande diminuição dos empregos formais, ocasionando a transferência de milhares de trabalhadores para a economia informal, situação em que o tempo e o interesse em participar das mobilizações é menor. O segundo é o apoio da política econômica à contratação de mão-de-obra com custos reduzidos, não filiada a sindicatos e sem direitos trabalhistas. Em terceiro, a forma como essa economia informal encontra nas ONG's suporte para

\footnotetext{
${ }^{15}$ Vice de Collor que o substituiu após a aprovação do processo de impeachment.

${ }^{16}$ Em 1989, Luiz Inácio Lula da Silva (PT) perdeu o segundo turno das eleições para Fernando Collor de Mello (PRN).
} 
sua estrutura e quarto, o crescimento do número de moradores de rua e dos indicadores de violência urbana. Além desses, será também relevante a crise de moral instalada nos três poderes da República.

Nesse contexto, poderão ser identificados como movimentos sociais significativos na década de 90, o Movimento pela Ética na Política ${ }^{17}$, a Ação da Cidadania contra a Miséria e pela Vida, o Movimento Nacional de Meninos e Meninas de Rua, o Movimento dos Aposentados, o Viva Rio, o Movimento Sou da Paz em São Paulo e tantos outros de cunho regional e municipal. Além desses, o MST espalha-se por todo o país, tornando-se o maior movimento popular da década ${ }^{18}$ atual.

Para o movimento sanitário, a consolidação de mais de 2000 conselhos de saúde por todo o País, nas três esferas de governo, representa a possibilidade concreta de se consolidar a participação popular, passo fundamental para que os movimentos populares obtenham as conquistas desejadas. No entanto, a utilização dos conselhos significou a institucionalização de uma parte expressiva da estrutura orgânica dos movimentos, contribuindo para uma onda de desmobilização e esvaziamento nas bases do movimento, reordenando as preocupações de seus atores e reprogramando as organizações populares.

Nas análises de GOHN (1997) sobre parte dos anos 90, a partir da ascensão dos partidos socialistas e sociais democráticos ao poder ${ }^{19}$ e com a garantia legal da criação de espaços de participação a partir de 88, ocorre uma mudança na preocupação dos movimentos, no sentido de capacitar as lideranças populares para sua atuação nos conselhos de saúde ${ }^{20}$. Para a autora, a questão que se apresenta nessas discussões é a seguinte:

\footnotetext{
${ }^{17}$ Decorrente do Movimento Fora Collor que levou às ruas milhões de brasileiros, principalmente os estudantes "caras pintadas", pedindo o impeachment do então presidente.

${ }^{18}$ Chama atenção a inversão da orientação predominantemente urbana dos movimentos populares das décadas de 80 e 90 feita pelo MST, que surgiu em 1979 no Estado de SC.

${ }^{19}$ Ênfase maior às administrações do PT, PSDB, PDT e PSB.

${ }^{20}$ Além dos Conselhos de Saúde, várias outras esferas de participação foram institucionalizadas, como as APM's; os Conselhos Tutelares; as experiências de orçamento participativo; as câmaras técnicas, entre outros.
} 
Não se trata apenas de reivindicar, pressionar ou demandar. Tratase agora de fazer, de propor, de ter uma participação qualificada, já que o lugar da participação está inscrito nas leis, é uma realidade virtual (GOHN 1997, p. 288).

E a criação dos espaços de participação, que se deu através dos conselhos de saúde, irá apresentar-se ao menos de duas formas distintas: como o instrumento que leva para dentro do aparelho jurídico institucional do Estado parte dos movimentos populares de saúde, principalmente através da participação de alguns de seus principais atores (lideranças) nesses espaços; e como a frente de implementação do SUS no Brasil, a partir de um amplo e conflituoso processo de, nas palavras de COHN (1996), "articulação entre democracia política e democracia social".

A distinção das duas questões colocadas acima será no entanto compreendida como de não oposição, à medida que a transição democrática vivida nos anos 80 provocou no Estado seu reposicionamento em relação aos movimentos populares, senão em relação à sociedade de maneira geral. Segundo RAMOS (1996), embora os conselhos de saúde sejam interpretados, em alguns momentos, como uma composição "possível” entre Estado e sociedade (uma idéia de pacto de cidadania controlada), não há como negar, segundo a autora,

Que os conselhos de saúde podem ser definidos como um projeto preocupado em assegurar a presença da sociedade civil, de forma realmente efetiva, participativa, na defesa dos interesses da população, na geração de políticas do setor, no acompanhamento da consecução das mesmas e na avaliação do sistema como um todo (RAMOS 1996, p. 331).

No contexto do presente trabalho, o estudo das relações entre o PROUNI e os movimentos populares de saúde na região Sul de Londrina tornar-se-á, muitas vezes, o estudo das relações entre o PROUNI e o Conselho de Saúde da Região Sul (CONSUL). 
Embora o CONSUL não tenha sido criado como parte do arcabouço jurídico institucional do aparelho de Estado, sua organização atual faz com que cumpra um papel de agente institucionalizador dos demais movimentos populares locais. Esse aspecto simboliza o que têm sido, nos últimos anos, os caminhos percorridos pelos movimentos populares de saúde no Brasil.

A continuidade da presente discussão se dará através das reflexões elaboradas no presente trabalho, a partir da construção da análise das categorias construídas. Estas, por sua vez, apresentam-se relacionadas a toda a temática discutida neste capítulo: articulação, autonomia, organização, parceria, cultura política, oposição e participação. 


\section{CARACTERIZAÇÃO DO MUNICÍPIO DE LONDRINA}

Londrina está situada na região norte do Estado do Paraná, a $379 \mathrm{Km}$ da capital, Curitiba. Tendo $2119 \mathrm{~km}^{2}$, ocupa 1\% do território do Estado, sendo o centro econômico e cultural de referência para uma região de cerca de um milhão e meio de habitantes. O clima local caracteriza-se como subtropical úmido, com temperaturas que oscilam entre 27 e $15,5^{\circ} \mathrm{C}$ nas estações de verão e inverno respectivamente $^{21}$ (PML/ASMS 1996).

A região de Londrina sofreu grande imigração nas décadas de 50 e 60, ocasionada principalmente pelo crescimento vertiginoso da cafeicultura que conferiu à cidade o título de capital mundial do café nos anos 60 . Conseqüência de uma constante urbanização, Londrina, hoje com 65 anos, possui uma população de 421.343 habitantes (IBGE 1997).

Sua população distribui-se pelo território municipal de forma a concentrarse no extremo norte, onde está a zona urbana, com $94,89 \%$ dos habitantes (PML/ASMS 1996). A pequena parcela rural da população encontra-se distribuída em vários distritos, principalmente na região Sul ${ }^{22}$ (RODELLO 1998).

A pirâmide populacional do município ${ }^{23}$ revela uma concentração da população nas faixas etárias entre 30 e 59 anos. A população acima de 60 anos soma $7,32 \%$ do total, enquanto a população de 0 a 4 anos alcança os $10 \%$ (PML/ASMS 1996).

A região onde vem se desenvolvendo o PROUNI apresenta 96.000 habitantes, cuja distribuição entre população urbana e rural é de $84 \%$ para $16 \%$ respectivamente (RODELLLO 1998). Tendo em vista um acelerado processo de urbanização vivido ao final da década de 70 e anos 80 , a zona urbana Sul é uma

\footnotetext{
${ }^{21}$ Observar o mapa do município de Londrina no Anexo 3.

${ }^{22}$ Os distritos são Lerroville, Irerê, Warta, Paiquerê, Maravilha, São Luís, Guaravera e Espírito Santo. Há 3 anos, o então distrito de Tamarana optou pela autonomia administrativa e constituiu um município.

${ }^{23}$ Ver Anexo 4.
} 
das regiões do município que apresenta o maior número de bairros carentes. Ainda hoje, apesar de recentes avanços na expansão de saneamento básico e energia elétrica, da construção de escolas e melhoria dos serviços de saúde, os maiores bolsões de miséria do município ainda se encontram nessa região.

\subsection{PERFIL EPIDEMIOLÓGICO}

Esta breve descrição de algumas informações epidemiológicas pretende fornecer informações elementares para aqueles que entrarem em contato com este material, proporcionando-lhes uma visão mais ampla do município e, em conseqüência, do cenário onde este estudo de caso foi desenvolvido.

Alguns dados de morbidade e mortalidade podem refletir, ainda que parcialmente, o estado de saúde da população local. A mortalidade em Londrina apresenta a seguinte distribuição:

Tabela 1 - Mortalidade proporcional em Londrina no ano de 1997.

\begin{tabular}{lc}
\hline Grupo de Causa & $\%$ \\
\hline & \\
Doenças do aparelho circulatório & 35,0 \\
Neoplasias & 18,8 \\
Causas externas & 12,0 \\
Doenças do aparelho respiratório & 9,3 \\
Algumas doenças infecciosas e parasitárias & 5,5 \\
Doenças do aparelho digestivo & 5,0 \\
Doenças endócrinas, nutricionais e metabólicas & 3,7 \\
Outros & 10,7
\end{tabular}

Fonte: Dados do Núcleo de Informação em Mortalidade da Diretoria de Informações em Saúde / PML/ASMS.

O Coeficiente de Mortalidade Infantil sofreu uma transformação significativa nos últimos 25 anos. Ao longo do processo de organização da rede de serviços de 
saúde e posteriormente da implementação do SUS, o CMI regrediu de 76,47 por mil nascidos vivos em 1974, para 13,40 por mil nascidos vivos em 1998, como mostra a Tabela 2.

Tabela 2 - Coeficiente de Mortalidade Infantil em Londrina entre 1974 e 1998.

\begin{tabular}{lc}
\hline Ano & CMI \\
\hline 1974 & 76,47 \\
1975 & 75,17 \\
1976 & 68,13 \\
1977 & 53,86 \\
1978 & $* *$ \\
1979 & 37,01 \\
1980 & 33,59 \\
1981 & 28,53 \\
1982 & 32,67 \\
1983 & 27,56 \\
1984 & 30,84 \\
1985 & 22,69 \\
1986 & 27,44 \\
1987 & 27,12 \\
1988 & 26,79 \\
1989 & 23,47 \\
1990 & 22,61 \\
1991 & 19,72 \\
1993 & 19,14 \\
1994 & $* *$ \\
1995 & 18,39 \\
1996 & 15,10 \\
1997 & $* *$ \\
\hline & 13,20 \\
\hline
\end{tabular}

Fonte: 1974 a 1977 (ALMEIDA 1979); 1979 a 1995 (PML/ASMS 1996); 1978, 1993 e 1996 não disponível; 1997 e 1998 (PML/ASMS/SIM/SINASC).

É ainda importante ressaltar que $\mathrm{CCMI}^{24}$ por regiões no ano de 1998 apresentou-se da seguinte forma: 11,90 no Centro; 18,40 na região Norte; 9,80 na Oeste; 12,70 na Sul; 11,00 na Leste e 19,30 na zona rural. Entre os anos de 1994 e 1998, o CMI teve uma melhora significativa na região Sul do município, regredindo de 28,70 para 12,70 . 
Os dados de morbidade disponíveis referem-se a algumas doenças de notificação compulsória. Quanto aos demais indicadores, merece atenção o fato da incidência de casos de AIDS por cem mil habitantes ter aumentado de 2,64 em 1989 para 13,31 em 1994 (PML/ASMS 1996). Além disso, a insuficiência cardíaca, broncopneumonia, AVE, hemorragias digestivas e pielonefrites aparecem dentre as causas mais freqüentes de internação hospitalar (PML/ASMS 1996).

Tabela 3 - Número de casos de algumas DNO - 1997.

Doença

Diarréia aguda

Conjuntivite viral

Varicela

Hepatite viral

Intoxicações

DST

Caxumba

Rubéola

Meningites

Sarampo

Dengue

Tuberculose

Teníase

Leishmaniose

Hanseníase

Cisticercose

Tétano

Coqueluche

Leptospirose

Malária

Difteria

\section{Número de Casos}

13175

5035

2355

525

443

393

213

188

226

115

86

44

22

20

19

12

9

8

7

3

1

Fonte: Dados do Registro de Doenças de Notificação Obrigatória de 1997 / Autarquia dos Serviços Municipais de Saúde de Londrina / Prefeitura do Município de Londrina.

${ }^{24}$ Dados obtidos junto à equipe de geoprocessamento da PML/ASMS. 


\subsection{BREVE HISTÓRICO DOS SERVIÇOS DE SAÚDE}

As descrições e análises do processo de organização e consolidação dos serviços de saúde em Londrina e a construção do SUS no município revelam um cenário técnico-político de vanguarda, ao longo das últimas três décadas.

Até o final da década de 60 , os serviços de saúde estiveram organizados, segundo a política vigente no País, ou seja, dando privilégios à atenção médicohospitalar com uma forte divisão entre ações de cura e prevenção. Contudo, iniciou-se em Londrina, no ano de 1969, o processo de descentralização dos serviços de saúde. Ao lado da criação da Secretaria do Bem-Estar Social e do Pronto Socorro Municipal ${ }^{25}$, um convênio entre a prefeitura e a UEL ${ }^{26}$ garantiu a implantação das duas primeiras UBS de bairro na zona urbana: a UBS da Vila Fraternidade, em 1970, e do Jardim do Sol, em 1971 (ALMEIDA 1979).

No período de 1972 a 1976, em meio à reestruturação da Secretaria de Bem-Estar Social, que passou à Secretaria de Saúde e Promoção Social ${ }^{27}$, surgiu a primeira UBS rural no distrito de Paiquerêe ${ }^{28}$. Em 1974, ao promover o PROCAF em convênio com a FWKK e a OPS, a universidade ampliou o atendimento médico na periferia da cidade com ênfase em ações de atenção primária à saúde voltadas ao grupo materno-infantil (ALMEIDA 1979).

Em 1977, ano marcado pela ênfase nas ações de APS, mais quatro UBS foram implantadas sob administração direta da prefeitura, sendo na Vila Nova e no Jardim Bandeirantes as de zona urbana, e em Irerê e Tamarana as de zona rural (ALMEIDA 1979). Não desconsiderando outros fatores, destaca-se que, no período de implantação de UBS, a mortalidade infantil em Londrina reduziu-se em quase 40 pontos.

\footnotetext{
${ }^{25}$ Leis Municipais 1578/69 e 1639/70 respectivamente.

${ }^{26}$ Procurava-se implementar a proposta de Medicina Comunitária.

${ }^{27}$ Lei Municipal 2297/73.

${ }^{28}$ Inaugurada em 1972.
} 
O modelo de serviços adotado nas unidades de saúde da rede que se constituía baseava-se no estreitamento da relação entre os futuros médicos ainda estagiários das UBS - e a comunidade (FUJIWARA et alii 1997). Segundo RODELLO (1998), Londrina foi um dos primeiros municípios brasileiros a adotar os princípios propostos pela Conferência de Alma Ata, em relação a APS.

Em 1978, foram implantadas UBS no Conjunto Habitacional Ruy Virmond Carnascialli, zona urbana, e em Maravilha, Warta, Lerrovile e Guaravera, estes na zona rural (ALMEIDA 1979). Em 1979, inauguraram-se postos no Conjunto Roseira $^{29}$ e no Jardim Leonor, e o posto Ody Silveira, no centro da cidade. Assim, Londrina encerrava a década de 70 com quinze UBS distribuídas pela cidade, estando 14 delas em regiões periféricas.

Nesse cenário de organização dos serviços municipais de saúde, os princípios de hierarquização e regionalização dos serviços e a integralidade das ações já eram apresentados (FUJIWARA et alii 1997). A presença dos traços de vanguarda pode ser ainda identificada na fala de uma das trabalhadoras da época:

"Na época das carteirinhas do INAMPS, a gente falava: - Não, aqui ninguém precisa disso, o Sr. é um cidadão. A gente explicava o princípio que hoje está escrito na carta constitucional". ${ }^{30}$

É importante salientar ainda que nesse período, tendo em vista a articulação de sanitaristas e estudantes que trabalhavam nas UBS, algumas movimentações populares ocorreram nas regiões de periferia. Como exemplo, pôde-se identificar os trabalhos na Vila Habitacional de Interesse Social (VISP) no Parque das Indústrias ${ }^{31}$. Parte dessas mobilizações tornaram-se importantes na ampliação da rede de UBS que viria a ser feita na década de 80 .

Entre 1980 e 1988, foram inauguradas mais 26 unidades de saúde, sendo 6 na zona rural e vinte na zona urbana. Esse salto deve-se principalmente à

\footnotetext{
${ }^{29}$ UBS dos Jardins Piza/Roseira.

${ }^{30}$ Entrevista ao autor.

${ }^{31}$ Anotação no diário de campo, a partir de conversas com trabalhadores dos serviços à época.
} 
proposta de descentralização da atenção à saúde conduzida pelo grupo que coordenou as políticas da SES/PR entre 82 e 86 , e que pôde contar com os repasses financeiros do convênio realizado com o MS através das AIS. Ao entrar nos anos 90, Londrina contava com 41 unidades básicas de saúde.

Com as eleições municipais de 1992, ascendeu ao poder executivo municipal a coligação "Londrina na Frente", resultado de articulações entre o PT e demais partidos de esquerda: PDT, PPS, PCdoB e PSB (SILVA 1996).

O apoio explícito do grupo ao processo de reforma sanitária e de implantação e implementação do SUS, mais uma vez conferiu a Londrina condições para consolidar o trabalho de construção da rede de saúde iniciado anteriormente. Segundo SILVA (1996) o plano de saúde apresentado à população na campanha eleitoral viria a ser cumprido nos anos seguintes. Em 1995 Londrina seria um dos primeiros municípios brasileiros a credenciar-se na gestão semiplena dos serviços de saúde de acordo com a NOB 1/93.

Entre 1992 e 1995 mais seis unidades de saúde foram inauguradas na zona urbana. Além disso, duas unidades rurais foram reinauguradas, um amplo processo de adequações físicas foi executado em mais de uma dezena de unidades, e outros programas foram implantados para a melhoria de gestão dos serviços (SILVA 1996).

Ao final de 1995 um saldo extremamente positivo foi deixado pelo trabalho realizado nesse quatriênio. Dentre as características mais importantes estão a elaboração do Plano Municipal de Saúde; a criação de um sistema integrado de informação em saúde, contando com o NIM, o SINASC, o SISVAN, o SISCAT e o SINAN; a criação de um sistema informatizado de prontuários, proporcionando também agendamento, exames e dados de produção; a implantação de um sistema de geoprocessamento ${ }^{32}$; a realização do GERUS; a realização de oficinas

\footnotetext{
${ }^{32}$ Observar nos Anexos 5 e 6 as áreas de abrangência das Unidades Básicas de Saúde da Zona Urbana do município de Londrina e, no Anexo 7, relação de todas as unidades de saúde urbanas e rurais.
} 
de PES nas unidades de saúde ${ }^{33}$; a implantação dos programas de AIDS e de outros grupos de pacientes; a implantação do PID e do PSF; e a implantação dos NAPS (SILVA 1996).

A partir de 1996, sendo a gestão municipal conduzida por outra coligação partidária, algumas modificações foram impressas à dinâmica anterior dos serviços. A proposta de implantação de um programa de Município Saudável, baseada em recentes documentos internacionais como a Carta de Otawa, parece não ter encontrado o lastro sociopolítico necessário.

Do ponto de vista estrutural, chegou-se à marca de 50 UBS, a partir da construção de uma unidade central e duas outras na região Sul do município. No entanto, as modificações realizadas na política de saúde municipal acabaram por diminuir a velocidade da municipalização em Londrina, sendo que muitos atores importantes nesse processo histórico da construção dos serviços de saúde afastaram-se da ASMS.

Apesar dessa discussão não ser o objeto central do trabalho, algumas leituras do momento atual poderão ser encontradas no capítulo 7 , onde os resultados obtidos no trabalho de campo são discutidos.

33 O desenvolvimento das oficinas de PES nas UBS, a implantação do Sistema de Geoprocessamento e a realização do GERUS foram atividades apoiadas pelo PROUNI-Londrina. 


\section{OBJETIVOS}

Analisar o papel do PROUNI Londrina na organização dos movimentos populares de saúde na região sul do município de Londrina.

\subsection{OBJETIVOS ESPECÍFICOS}

a) Descrever e analisar o processo histórico de organização dos movimentos populares em saúde na região sul.

b) Localizar, descrever e analisar, a partir de depoimentos de membros dos três componentes do PROUNI, os espaços e mecanismos de participação popular na gestão do PROUNI.

c) Verificar e analisar a influência do PROUNI e dos movimentos populares de saúde na região sul, no desenvolvimento de outros movimentos populares em saúde no município.

d) Descrever a história de organização do CONSUL. 


\section{METODOLOGIA}

Dada a natureza do objeto de estudo e os objetivos anteriormente apresentados, o presente trabalho foi estruturado como um estudo de caso e realizado a partir de informações obtidas em entrevistas semi-estruturadas e em pesquisas documentais, além de ter contado com contribuições não formais da etnografia, em um processo de observação não participante.

Tal abordagem pareceu mais adequada à promoção do exercício da práxis interpretativa ${ }^{34}$ que foi muito útil para que este trabalho pudesse apresentar análises concretas da dinâmica do fenômeno em foco: os movimentos populares de saúde, cuja realidade aqui se apresenta em seus aspectos fundamentais.

A investigação realizada pode ser definida, segundo ZIONI (1994), citando Bruyne (1982), como:

Um estudo em profundidade, isto é, uma análise intensiva empreendida numa única ou em algumas organizações reais (....) Reúne informações tão numerosas e detalhadas quanto possível com vistas a apreender a totalidade de uma situação (....) Por isso recorre à técnica de coleta de informações igualmente variadas (observações, entrevistas, documentos ...). Alguns têm o intento de exploração (...) outros são essencialmente descritivos e tomam forma de uma monografia (ZIONI 1994, p. 65)

Este trabalho compreendeu uma fase inicial de ampla revisão bibliográfica, para construção do marco teórico e escolha das técnicas de coleta e interpretação dos materiais obtidos em campo. Houve ainda um processo de aproximação do campo de trabalho, em que foram estabelecidos os primeiros contatos com os atores relacionados ao objeto.

\footnotetext{
${ }^{34}$ Ato de pensar, agir e interagir com a informação obtida pela pesquisa de campo. A práxis interpretativa tem ainda o sentido de atividade livre, autêntica e consciente, em oposição à postura alienada.
} 
Foi também apresentada à comissão gestora do PROUNI-Londrina uma proposta de trabalho que recebeu aprovação e apoio financeiro do Fundo de Apoio à Pesquisa UNI. A apresentação da proposta para a CIGO, em particular para os representantes da comunidade nessa comissão, ocorreu em virtude da preocupação ética dos pesquisadores envolvidos, sendo que sua aprovação garantiu o respaldo necessário para o trabalho de campo.

\subsection{TÉCNICAS DE COLETA DE DADOS}

Foram utilizadas as seguintes técnicas:

1) Entrevistas semi-estruturadas com informantes-chave pertencentes aos três componentes do PROUNI: Academia, Serviços de Saúde e Comunidade.

2) Grupo focal que incluiu representantes das entidades comunitárias ligadas aos movimentos populares de saúde na região Sul do município de Londrina.

3) Informações complementares em panfletos, boletins, artigos, atas de reuniões, jornais locais, entre outros documentos.

Utilizou-se ainda um diário de campo para o registro de algumas observações de caráter não sistemático, visto que não se guiaram por regras anteriormente estabelecidas nem precisaram de instrumentos específicos. As observações foram apenas utilizadas como contribuições etnográficas ao conjunto da metodologia. ${ }^{35}$

\footnotetext{
${ }^{35}$ Os roteiros das entrevistas e do grupo focal encontram-se no Anexo 8.
} 


\subsection{AMOSTRA}

O formato qualitativo do presente trabalho dispensou critérios amostrais estatísticos. Foram assumidos como fontes dos dados os informantes-chave ${ }^{36} \mathrm{e}$ uma série de documentos e observações.

Os informantes-chave foram vinte três ao todo, sendo que se procurou envolver pessoas dos três componentes do PROUNI-Londrina. A lista abaixo identifica os atores entrevistados.

a) Quatro informantes-chave provenientes dos movimentos populares de saúde da região Sul de Londrina.

b) Quatro informantes-chave provenientes da academia, mais especificamente do CCS/UEL, todos eles com participação direta nas atividades do PROUNI-Londrina.

c) Quatro informantes-chave provenientes dos serviços de saúde, tanto da gestão atual quanto anterior.

d) Quatro representantes dos Conselhos Regionais de Saúde das Regiões Norte, Centro, Leste e Oeste de Londrina.

Quanto ao grupo focal, sua utilização baseou-se no preceito de que tal método, como uma técnica de pesquisa qualitativa, ajudaria o pesquisador a realizar um processo de triangulação entre as fontes de dados, conferindo maior amplitude à coleta e à interpretação dos materiais.

\footnotetext{
${ }^{36}$ Segundo MAGENDZO e TOLEDO (1992), " informante clave es una persona que es conocedora del tema a analizar y que se presta voluntariamente a entregar cierta información. Es una persona que conoce bien su sociedad, comunidad, grupo, etc.; una persona que está directamente relacionada con el tema de la entrevista; una persona que cuenta con el tiempo suficiente para contestar la entrevista; una persona que hace más descripciones que interpretaciones de los hechos sobre los cuales trata la entrevista."
} 
O grupo constituiu-se de pessoas escolhidas por apresentarem traços importantes ao estudo proposto. No caso, a participação nas entidades que constituem a base dos movimentos populares de saúde na região Sul do município de Londrina.

1. Quatro representantes de associações de moradores da zona urbana.

2. Dois representantes do movimento de mulheres da zona rural.

3. Um representante do movimento de mulheres da zona urbana.

\subsection{REGISTRO DAS INFORMAÇÕES}

Utilizou-se um gravador para fita cassete de sessenta minutos e o diário de campo. As fitas foram transcritas ao final de todas as entrevistas pelo próprio pesquisador. O grupo focal também foi gravado e transcrito, assim como as entrevistas.

\subsection{ANÁLISE DOS RESULTADOS}

Utilizou-se a análise temática, através da identificação e da construção de categorias analíticas, a partir de leituras exaustivas das entrevistas e do grupo focal transcrito, bem como da análise documental complementar.

Construiu-se e adotou-se, portanto, um conceito de categoria como o espaço teórico capaz de traduzir ao pesquisador parte das informações necessárias ao alcance dos objetivos inicialmente propostos para a pesquisa. 
Tomando-se o objeto de estudo como um polígono formado por $n$ faces transparentes, cada uma dessas faces assumiria o conceito de categoria, uma vez que permitiria a qualquer observador externo obter uma visão particular do conteúdo do polígono (objeto) por essa janela virtualmente construída. As categorias simbolizam uma abstração e permitem ordenar a realidade, segundo critérios definidos pelo pesquisador.

$\mathrm{Na}$ análise temática adotada, é possível identificar a presença de determinados temas que, metaforicamente, saltam aos olhos do pesquisador, permitindo seu encaixe e análise nas categorias que estão sendo estabelecidas.

"O tema é a unidade de significação que se liberta naturalmente de um texto analisado segundo critérios relativos à teoria que serve de guia de leitura“" (BARDIN 1988)

Antes de fazer breves reflexões sobre cada uma das categorias, é preciso ressaltar que, ao constituírem o mesmo objeto, é natural que sua apresentação não seja estanque e que não existam limites iniciais e terminais, cartesianamente definidos.

Assim, ainda que o capítulo seguinte, onde são apresentados e discutidos os resultados, seja dividido conforme as categorias abaixo descritas, essa opção se deu apenas para tornar o trabalho de análise mais simples e apresentá-lo de forma mais didática.

\subsection{CATEGORIAS ANALÍTICAS}

Para maior clareza do foco das observações sobre os resultados, as seguintes categorias foram definidas: 
1. A articulação de um movimento popular está relacionada tanto a sua conjuntura interna quanto externa. Deve ser compreendida principalmente a partir de um elemento fundamental: a capacidade das pessoas para exercer liderança. É o exercício da liderança que vai garantir ao movimento a articulação necessária entre as demandas apontadas pela base, os grupos de coordenação, os grupos demandatários, os setores opositores, entre outros. A articulação contribui ainda para a consolidação das relações entre os diversos movimentos presentes em um mesmo cenário geopolítico, a fim de que as forças populares possam ser somadas às lutas gerais. O papel de interlocução desenvolvido pela liderança é essencial para a articulação e o posterior êxito do movimento.

A capacitação é um processo em que a população passa a assumir gradativamente o seu próprio processo de conscientização e organização e se torna capaz de estender a sua experiência ao todo social, penetrando mais a fundo na essência dos problemas e captando as contradições sociais a que se está submetida. Como tal, percebendo mais a essência da sua realidade social, tenta encontrar novos modos de agir que respondam mais diretamente aos seus problemas (SOUZA 1993, p. 95).

A composição do movimento diz respeito aos grupos e setores que se articulam e se aglutinam para a constituição de um todo que, diga-se de passagem, nem sempre se apresenta homogêneo. O critério mais evidente dessa aglutinação é a agenda demandatória de cada um desses grupos que, em ao menos um ponto, unificar-se-á.

2. A autonomia pode ser compreendida como o momento a partir do qual o movimento popular possui condições de exercer funções de organização e reivindicação, sem a interferência de atores sociais que apresentem interesses direta ou indiretamente contraditórios aos interesses do movimento.

Retomando CHAVES e KISIL (1994), a importância do protagonismo ativo da comunidade nos projetos UNI encontra-se no reconhecimento de que o grupo é 
o sujeito do processo de desenvolvimento, conduzindo as mudanças segundo sua própria visão da realidade, suas expectativas e percepções.

3. A organização de um movimento popular diz respeito tanto à sua estrutura organizacional quanto à estrutura de sua rede colaboradora.

Usualmente, nas etapas iniciais existe uma organização informal. Com o tempo, a necessidade de formalização se impõe, com o estabelecimento de funções, divisões de tarefas, cargos, tempo de mandato, etc. (....). A organização possui níveis internos e externos, sendo este último elemento da rede de articulações (GOHN 1997, p. 259).

No aspecto organizacional, deverá se considerar a existência de instrumentos gerenciais para o movimento, como o planejamento, a avaliação, as assessorias, entre outros.

4. A parceria é o processo pelo qual atores sociais distintos colaboram entre si nas mais variadas formas, a fim de que os objetivos gerais possam ser atingidos com ganhos para todos. Independente das diferentes condições políticas, culturais, sociais ou econômicas primárias dos grupos parceiros, está garantido a todos o direito de participar ativamente do processo de tomada de decisões. É ainda uma das dimensões presentes no arcabouço teórico de Avaliação de Cluster do Programa UNI, sendo considerada como um de seus princípios realmente inovadores em relação a outras estratégias de desenvolvimento de trabalhos em conjunto (FWKK 1997a).

5. A cultura política de um movimento popular se constrói a partir da experiência vivenciada no cotidiano (GOHN 1997). É um processo que se estrutura a partir das experiências vividas no enfrentamento dos problemas e na construção da organização de um movimento. É preciso compreender, nesta análise, a postura ideológica dos sujeitos do movimento, principalmente de suas principais lideranças, as relações políticas desenhadas, interna e externamente ao movimento, e ainda suas práticas políticas. Compreendem-se as práticas 
como o conjunto de ações desenvolvidas pelo movimento, no sentido de atingir os objetivos estabelecidos por ele.

Outro componente importante nessa abordagem é retratar a relação entre as reivindicações de um movimento social e sua capacidade propositiva. Parece haver uma relação transitória explícita entre as reivindicações que, geralmente, são iniciais em meio ao processo histórico, podendo ser de ordem econômica, política, social e cultural, e sua capacidade de propor soluções, de abrir agendas de negociação, de caminhar no amadurecimento das relações e práticas políticas, visando à conquista dos objetivos de um movimento.

6. A oposição a um movimento social se dá, geralmente, por sujeitos ou grupos sociais que detêm o poder sobre o bem demandado (GOHN 1997). É importante a compreensão dos conflitos que envolvem o movimento e os opositores bem como o conhecimento sobre as estratégias utilizadas particularmente por esses atores, através do tempo, à medida que interesses e ânimos vão ganhando maiores aspectos de disputa, conforme aumenta o poder de pressão do movimento.

7. O conceito participação tem sido utilizado para descrever diversos processos de relação de poder entre dois ou mais atores em uma sociedade, estejam esses em posições concorrentes ou não. Faz-se necessário, logo de início, tomar a participação em um contexto democrático, já que em muitas oportunidades, práticas e discursos intitulados de participação, o conceito tem servido apenas para a reprodução de processos de dominação, por conseguinte, "processos de contraparticipação" (SOUZA 1993). 


\section{RESULTADOS E DISCUSSÕES}

A análise temática do material obtido no trabalho de campo proporcionou um conjunto expressivo de informações relacionadas ao alcance dos objetivos deste trabalho. Adotando-se as categorias de análise descritas no capítulo anterior, assegurou-se a percepção de inúmeras propriedades dos movimentos populares de saúde em Londrina e suas relações com o PROUNI, o que traduziu parte da sua realidade. Os resultados apresentados e discutidos neste capítulo procuram expressar essa visão da realidade ${ }^{37}$.

Para facilitar o entendimento das falas que aparecem adiante e para melhor localizá-las no espaço sociopolítico onde foram construídas, optou-se por apresentar, antes de cada uma delas, a letra imediatamente correspondente ao grupo de origem do ator social, de acordo com a classificação adotada pelo PROUNI:
(A) Falas de atores da academia (CCS/UEL);
(C)Falas dos atores da comunidade;
(S) Falas dos atores da Autarquia Municipal dos Serviços de Saúde.

\footnotetext{
37 No restante deste capítulo, os trechos das entrevistas transcritas conservaram os erros gramaticais cometidos pelos atores entrevistados, procurando manter a originalidade dos diálogos e das expressões.
} 


\subsection{UM MOVIMENTO ARTICULADO}

Para analisar a articulação dos movimentos populares da região Sul de Londrina, foram construídos e utilizados alguns critérios específicos. O primeiro deles foi a capacitação de lideranças, ponto que tem sido fundamental para a sustentação da articulação do movimento. Portanto, vale a pena retomar o marco teórico anteriormente fundamentado, onde, segundo GOHN (1997), a questão da capacitação das lideranças dos movimentos populares, durante a década de 90 , foi uma das maiores preocupações a partir da materialização dos espaços de participação criados pelo regime democrático, especialmente a partir de 1988: os conselhos de saúde.

Nas entrevistas, o tema capacitação de lideranças apareceu ao menos de duas maneiras diferentes. Em primeiro lugar, envolvendo diretamente a argumentação teórica anterior, aparece o esforço dos movimentos populares em capacitar um número cada vez maior de pessoas, oferecendo-lhes instrumentos técnicos e políticos para o exercício de suas funções, como se percebe nas falas selecionadas:

(C) "E essas associação de mulher, elas têm assim um perfil diferente das associação de morador. Em primeiro lugar, elas trabalha a questão da capacitação e responsabilidade da liderança."

(C) "A gente trouxe aqui em 95 a Dra. Carmem pra discutir a questão dos SILOS, que é a oficina de territoriamento. O SILOS, onde você poderia discutir o que é o SUS, o conhecimento base de saúde, aonde que fica o recurso. Isso foi um curso proposto pra 35 liderança, né. Os Conselhos Locais, as Associação de Mulheres, as Associação de Moradores."

Em segundo lugar, surge o tema da responsabilidade das lideranças pela interlocução junto às esferas de controle do PROUNI-Londrina e em outras instâncias locais: 
(C) "Eu acho que a gente tem que cada vez mais tá ocupando espaço, tal e uma coisa que a gente tem que ter muito cuidado, muito zelo, é da gente não tá sendo absorvido... O que eu falo é o seguinte: eu começar a participar lá da reunião da CIGO e tal, e daqui a pouco eu tá conversando, pensando, agindo, igual ao serviço e a academia, e eu deixar de ser aquele elo de ligação. Por mais dificuldade, por mais situação ainda de pouco conhecimento, de participação que tiver a comunidade, eu tenho que ser o reflexo disso, eu tenho que levar isso lá pra CIGO."

Segundo as entrevistas e observações, o CONSUL tem promovido um grande número de encontros com o objetivo de capacitar lideranças. Em função desses eventos, o seguinte resultado é reconhecido por um dos documentos da organização:

Consolidação das lideranças inovadoras e condições para o aparecimento de novos líderes, para atuação micro-regional, municipal e em âmbitos maiores. Novas lideranças despontam na região, dando maior força ao movimento (CONSUL 1998b, p. 26).

Além da capacitação de lideranças, outra dimensão da articulação pôde ser verificada, a partir da existência de uma rede de entidades locais, compondo a base do movimento. Um fator importante nessa rede é a presença dos movimentos da zona rural que, no cenário local, apresentavam-se tradicionalmente excluídos dos processos de participação. Conforme apresentado no capítulo 4 , são sete os distritos rurais, com aproximadamente $16 \%$ da população da região Sul do município (RODELLO 1998).

Através das observações e depoimentos colhidos no grupo focal, onde dois dos sete atores representavam movimentos rurais (distritais), foi possível reconhecer que várias ações têm sido implementadas para a diminuição da distância entre as populações rural e urbana. Além da breve passagem abaixo extraída da análise documental, foi possível encontrar registros da realização de 
algumas oficinas e reuniões na zona rural, principalmente vinculadas às associações de mulheres.

"Integração das lideranças para a luta conjunta urbana e rural" (CONSUL 1998b, p. 28).

Foi possível também extrair das falas dos atores, temas que destacam a articulação dos movimentos de base no CONSUL, além, é claro, de verificarem-se mais de cem entidades de base, desenvolvendo atividades em uma região de cerca de 96.000 pessoas:

(A) "Olha, o que eu acho que marca é como que consegue trabalhar junto e reunir os diversos movimentos diferentes. Eu, com o estágio de alunos nossos, trabalhamos com a Pastoral da Criança do Ouro Branco, e quando eu vou ver o CONSUL, tá lá a Pastoral da Criança, e a coordenadora do pastoral está ativamente participando. Sabe, então, de conseguir reunir os diversos movimentos que já existiam (...) as entidades que mantinham creches, escolas, as associações de moradores".

Ao longo dos oito anos de atividade do PROUNI, parece ter havido uma acentuada transição entre o estágio no qual se encontrava a articulação dos movimentos em 1991/92 e seu estado atual. Essa idéia de transição, expressa nas falas abaixo, acompanhará boa parte das discussões realizadas em cada uma das categorias.

(C) "Quando a gente começou a trabalhar nessa área comunitária, a gente percebia um desacerto muito grande entre as próprias pessoas mesmo. Como posso dizer, as próprias entidades até. Era a associação dos moradores trabalhando pra um lado, a associação de mulheres pra outro, o conselho de saúde num outro rumo, enfim, sempre nos mesmos objetivos, mas sempre um querendo bater no outro, um querendo crescer mais do que o outro, querendo ser mais do que outro. E nesse tempo que a gente trabalha aí, a gente tem trabalhado arrumando formas pra que isso não aconteça. Pra que 
seja todos que defenda uma mesma linha, mas que também trabalhe com uma mesma tese, trabalhe com uma forma de companheirismo dentro da área da luta comunitária (....), pra que todo mundo se entenda, porque os objetivo é os mesmos, é uma melhoria pra região, é uma melhoria pro bairro."

A articulação tem ainda como componente atores externos à região Sul. Embora as relações políticas entre os demais conselhos regionais de saúde em Londrina e o CONSUL sejam discutidas adiante, é importante saber que existe a intenção de fortalecer essa relação com o objetivo de atribuir maior poder aos setores populares da cidade. Entretanto, ainda é marcante o distanciamento que, atualmente, fragiliza a atuação global dos conselhos regionais:

(C) "Isso a gente tem tentado superar, tem conversado bastante com o pessoal dos Conselho e qual que é a nossa proposta ? Vamos criar uma discussão sobre saúde, sobre controle social, sobre participação dos usuários a nível municipal, vamos criar um movimento municipal ?"

Começa também a se fazer presente a articulação entre os movimentos locais e outros movimentos populares em nível Estadual e Nacional, o que garante a ampliação da agenda do CONSUL e de sua base, a melhoria do nível de informação e o intercâmbio de experiências.

(C) "Nós temos o Nelson, por exemplo, que é o coordenador da central de movimentos do Paraná. Nós temos a Dita, que agora foi recém-convidada pra assumir o cargo de coordenadora do setorial de mulheres. Nós temos aí o pessoal do MOPS, que também tá se manifestando no sentido de trazer a coisa do MOPS pra Londrina."

(C) "Aproximamos mais o contato com a central de movimentos populares, com outras discussões mais gerais do País; tivemos uma luta, assim que foi uma mobilização, que fez cidade inteira e até o Estado, ficar com a atenção voltada aqui para a região Sul, que foi 
na questão do transporte coletivo, a luta pela quebra do monopólio dos transporte coletivo."

Além disso, a articulação tem ganho muito com a estratégia - adotada pelo Programa UNI - de contribuir sistematicamente para o intercâmbio nacional e internacional entre os componentes dos projetos em toda América Latina. A partir da realização do II Seminario de Sistematización del Programa UNI - Desarrollo Integrado de Los Componentes Comunidad, Servicios e Academia (Miami 09/97), do Seminário de Avaliação PROUNI (Temuco 09/95) e do IV Encontro Nacional de Lideranças Comunitárias dos Projetos UNI (Londrina 06/98), são muito importantes os pontos sistematizados e que devem ser adotados, segundo o documento, na condução dos trabalhos no componente comunidade ${ }^{38}$.

Foi possível ainda reconhecer a articulação dos movimentos populares de saúde, em especial do CONSUL, na criação do CRESUL, que conferiu maior amplitude às ações populares de saúde, estendendo a rede de articulação popular e as discussões também para dentro das escolas de primeiro e segundo graus da região.

"Destaque deve ser dado ao CRESUL, que está se formando com uma proposta de articulação das áreas de saúde e educação, envolvendo escolas, APM's e creches da área" (CONSUL 1998b, p. 11)

Além desses, segundo o CONSUL (1998b), algumas articulações foram estabelecidas entre as entidades populares de base, a fim de que a mobilização comunitária pudesse promover algumas atividades necessárias à comunidade. Dentre essas articulações, citam-se as seguintes:

Pastoral da Criança: (...) alimentação alternativa, remédios caseiros, (....); Clube de Futebol da Região Sul: (....) futuro melhor para crianças e adolescentes (....); Ondas Livres: (...) curso de capacitação de Rádios Comunitárias; Comitê pelos Direitos

\footnotetext{
${ }^{38}$ Sugere-se a leitura do documento de síntese do IV ENLC apresentado no Anexo 9.
} 
Humanos: luta pelos direitos sociais e cidadania; Movimento Contra o Monopólio e pela melhoria da qualidade do transporte coletivo na região Sul (CONSUL 1998b, p. 19-20).

\subsection{UM MOVIMENTO LUTANDO POR AUTONOMIA}

Segundo GOHN (1997), a autonomia perdeu, durante ao anos 80, o status de categoria analítica importante que teve na década de 70 , deixando de aparecer com a mesma freqüência de antes, nas análises contemporâneas dos movimentos sociais, entre eles, os movimentos populares de saúde.

Como argumentado no marco teórico, tal mudança encontra-se apoiada na criação de inúmeros espaços de co-participação dos movimentos populares em câmaras, mesas de negociação e, em particular, nas conferências e conselhos de saúde. O Estado, que nas décadas de 70 e 80 fora o grande adversário, abandonou essa posição para se tornar, em muitas ocasiões, o principal interlocutor dos movimentos sociais (GOHN 1997). Apesar disso, a autonomia foi um dos temas mais presentes nas entrevistas feitas no campo, tornando necessárias as seguintes reflexões.

Em primeiro lugar, o tema surge das discussões sobre o apoio financeiro do PROUNI aos movimentos populares de saúde e ao CONSUL. Como os atores entrevistados apontam o fator recursos econômicos como fundamental, discuti-lo frente a autonomia dos movimentos - torna-se elementar. Tal discussão ganha novas dimensões ao tratar-se da auto-sustentabilidade dos movimentos, bem como ao perceber-se que um certo grau de independência em relação a grupos políticos locais tem conferido maior poder de pressão aos movimentos populares de saúde. 
No caso do CONSUL, a casa onde funciona sua sede, incluindo mobília e equipamentos de escritório, foi obtida com recursos do PROUNI repassados pela FWKK. Como demonstrado na entrevista abaixo, tal fato tem um sentido importante ao expressar uma certa "libertação" de amarras políticas que, com freqüência, acompanham grupos políticos por todas as partes:

(C) "E pra nós foi de fundamental importância. Até dessa questão aí da gente poder falar meio grosso com o poder e tal. Essa autonomia nossa vem muito disso não é? Se a gente dependesse de xerox, de telefone, de toda essa estrutura que foi adquirida através do projeto para nossa organização, de outra fonte que viesse, de alguma forma, do poder, da maneira que eles manipulam, da maneira que eles entendem, eu acho que a gente estaria muito atrás do que a gente está hoje."

(C) "Então nós não tem que pedir pro prefeito um centro comunitário pra fazer reunião, nós não tem que pedir telefone, não tem que ir lá pedir um passe de ônibus. Então isso dá uma autonomia de cidadania e onde você pode tá buscando mais fortaleza das liderança e aglutinar no CONSUL."

Por sua vez, em momento algum das entrevistas, dos documentos e mesmo das observações no campo, foi possível encontrar alusões ao fato de que a utilização dos recursos do PROUNI tenha gerado posturas de interferência da universidade nas organizações populares. As arestas ainda existentes, e que dizem respeito mais a relação com o poder público municipal, situam-se também fora da mesa de negociação dos três componentes (CIGO), questão que aparece nas discussões seguintes.

Segundo as entrevistas e as observações, uma análise complementar mostra também que, embora boa parte da estruturação do CONSUL e de algumas de suas atividades estejam ligadas aos recursos do PROUNI, existe uma percepção de que os recursos foram grandes responsáveis pelo salto inicial dessas atividades, bem como na formação dos pilares da autonomia; porém, 
outros fatores, ao longo do tempo, ganharam campo em relação aos recursos econômicos:

(A) "Não é que tudo que eles façam teve financiamento do PROUNI, pelo contrário, eles desenvolvem muita coisa sem financiamento nenhum do PROUNI e passam por dificuldades em algumas vezes."

(A) "Então o que eu estou querendo dizer é que o financiamento é uma coisa importante, mas que eles não dependem totalmente do Projeto UNI, eles desenvolvem suas atividades com recursos que eles conseguem de outras formas."

Em relação à captação de recursos, visando a organizações autosustentáveis, existem grandes dificuldades para sua efetivação. Isto se deve principalmente às precárias condições econômicas enfrentadas pela população, mas também a implicações culturais envolvidas no ato de contribuir com uma entidade qualquer.

Dentre as estratégias que têm sido utilizadas pelos movimentos populares para encontrarem alternativas de sustentabilidade econômica, está a realização de oficinas de confecção de trabalhos manuais que destinam às organizações uma pequena parcela da produção. Tais oficinas criam ainda a perspectiva de uma renda familiar complementar ao cidadão, estimulando a captação de mais participantes nas organizações.

Um fator que tem contribuído para a preocupação dos componentes do PROUNI para o tema da auto-sustentabilidade é a própria orientação do Programa. Na metodologia da avaliação do cluster dos projetos, a sustentabilidade econômico-financeira aparece como um dos critérios da institucionalização ${ }^{39}$ das mudanças decorrentes dos projetos (FWKK 1997a). A preocupação com organizações auto-sustentáveis está presente na fala seguinte:

\footnotetext{
${ }^{39}$ Além da institucionalização, outras oito dimensões compõem a avaliação: parceria, liderança, trabalho em rede e comunicação, auto-avaliação, desenvolvimento acadêmico, desenvolvimento dos serviços, desenvolvimento comunitário e pertinência das estratégias.
} 
(C) "Aí precisa ter um nível de organização, uma coisa transparente, e coisa e tal. Vamos imaginar assim: se começasse lá no morador, começasse com uma passagem de ônibus e chegasse aqui no CONSUL, as entidades tivesse uma contribuição mensal e aí o CONSUL contribuir com a central de movimentos populares. Então a gente precisa chegar nisso, mas ainda tamo muito aquém de chegar nisso, não dá nem pra colocar isso como discussão, infelizmente. Mas vai ter o momento que a gente vai ter que discutir, isso porque os financiamentos que vêm são limitados e sempre colocamos isto: tem a questão da contrapartida no primeiro momento, mas depois eles querem ver as organizações serem autosustentáveis. Só tem essa saída né, que eu vejo. Não posso imaginar outra que não seja auto-sustentável pelas pessoas que compõem essas organizações."

Em segundo lugar, a vertente que surge na análise da autonomia parece revisitar a interferência que o aparelho de Estado exerceu nos movimentos populares dos anos 60 e 70 . É retratada com muita força a difícil relação entre os movimentos populares e poder público local personificado no prefeito, em sua base de sustentação na Câmara de Vereadores e também na ASMS.

(C) "Nós estamos vivendo aqui em Londrina um governo populista, não é? E ele tentou, num primeiro momento, estabelecer uma relação de, vamos dizer, de cooptação do movimento. Então primeiro atendeu algumas reivindicações, depois começou a querer fazer conversa reservada com um, com outro, e tal. Isso não avançou, porque a gente já tinha um certo nível de consciência, de esclarecimento sobre essa questão."

(C) "Na gestão anterior da prefeitura, era um governo, pelo menos pretendia-se fazer uma gestão popular, democrática, e mesmo assim, todos os momentos quando precisou, a gente manifestar, protestar, a gente fez, e nesse momento populista, ele tinha essa preocupação em manter a gente debaixo das asas." 
A partir dos diálogos estabelecidos com alguns atores, durante o trabalho de campo e a partir da exaustiva leitura das entrevistas, é possível perceber certas atitudes de cooptação, de coação e de ingerência sobre os movimentos populares de saúde na região Sul de Londrina. Isso tem se dado principalmente a partir de lideranças locais com menor grau de participação no PROUNI e que, aparentemente, tenham um acúmulo menor de discussões políticas.

Embora esses registros possuam relações claras com a categoria autonomia, maior atenção será dada a esse aspecto ao lidar-se com a oposição aos movimentos populares de saúde. Mais uma vez, ressalta-se a relação dinâmica entre as categorias de análise construídas, que provoca nessa discussão a necessidade de que se realizem leituras que flutuem entre os temas discutidos pelo presente capítulo: discussões sobre autonomia também estão presentes nas análises da parceria e da cultura política.

\subsection{LUTA ORGANIZADA}

Em agosto de 1989, realizou-se em Londrina a $1^{\text {a }}$ Conferência Municipal de Saúde que teve como tema central as Políticas, Diretrizes e Linhas de Ação para a Implantação do Sistema Unificado de Saúde de Londrina. Nesse período, os movimentos populares de saúde resumiam-se a uma estrutura bastante simples, apoiada principalmente em movimentos isolados da periferia, com pouca articulação. A não ser pela presença de um representante de movimentos populares na coordenação de uma das mesas redondas da $1^{\text {a }}$ Conferência, não existem outros registros documentais ou passagens nas entrevistas que proporcionem impressões contrárias (SANTOS 1998).

Já na $2^{\text {a }}$ Conferência Municipal de Saúde, realizada em maio de 1991, oitenta e oito entidades da sociedade civil participaram das discussões. Dessas, cerca de quarenta relacionavam-se aos movimentos populares de bairro e aos 
movimentos religiosos (SANTOS 1998). Sua temática já apresentava as discussões sobre a criação do Conselho Municipal de Saúde e também do Fundo Municipal de Saúde.

Ainda em 1991, tanto na etapa de preparação que antecedeu a $2^{a}$ Conferência Municipal de Saúde, quanto nas mobilizações dela decorrentes, a discussão de implementação do SUS em Londrina resultou na organização da $1^{a}$ Conferência de Saúde da Região Sul (CONSUL 1998b).

A $1^{\text {a }}$ Conferência, realizada no dia 08 de dezembro de 1991 na sede da Associação de Moradores do Conjunto das Flores, durou um dia inteiro e teve a participação de mais de 400 pessoas de 40 bairros diferentes e de vários distritos rurais (PEREIRA 1994, p. 71).

A partir das discussões ocorridas nessa conferência, enriquecidas pelas lutas populares que, de forma modesta, vinham sendo travadas desde a década anterior, não só se concretizava a idéia de constituição de um conselho de saúde para a região, aproximando-se das conquistas expressas na Lei 8.142 que completava seu primeiro ano de vida, quanto emergia a proposta de participação no PROUNI-Londrina que, nesse mesmo período, dava seus primeiros passos.

Oportunamente, nasceu o CONSUL, trazendo como objetivo principal a participação direta no planejamento, formulação, controle e avaliação da política municipal de saúde para a região Sul de Londrina (CONSUL 1998a).

"O CONSUL surgiu no contexto das lutas populares (...) como uma força política da comunidade organizada da região, voltado às questões de saúde“ (CONSUL 1998b, p. 2).

Já na $1^{\text {a }}$ Conferência de Saúde da Região Sul, puderam ser observados traços marcantes do início de organização desse movimento:

Os trabalhos da $1^{\text {a }}$ Conferência foram precedidos por intensa mobilização comunitária para a discussão do instrumento de trabalho. Durante essa conferência, procurou-se fazer um 
diagnóstico da real situação de saúde da população e dos serviços de saúde a ela oferecidos para, a partir daí, levantar prioridades e discutir mecanismos de interferência nas deficiências apresentadas (CONSUL 1998b, p. 2).

E foram esses traços de mobilização e organização popular, ao lado de critérios geográficos, sócio-econômicos e administrativos, que motivaram o grupo de trabalho do PROUNI-Londrina ainda em 1991, a incorporar a região Sul ao projeto original. Porém, ao sintetizar a situação da organização da comunidade naquele momento, o grupo de trabalho concluía o seguinte:

"O movimento comunitário de saúde no entanto, ainda pode ser considerado incipiente e frágil, uma vez que a mobilização social é frágil no seu todo" (UEL 1992, p. 7).

Com as transformações ocorridas no período compreendido entre 1991 e 1999, um amplo processo organizacional desenvolveu-se tanto nas entidades de base dos movimentos populares, quanto naquela que se tornou sua maior e mais representativa instituição: o CONSUL. O movimento que, em 1991, iniciou o processo de participação no PROUNI, com reconhecidas deficiências em sua organização, encontrou na transformação de sua própria estrutura, a garantia dessa participação.

Em decorrência da realização de inúmeras atividades de capacitação, dos apoios econômico e gerencial, da nova condição política, entre outros, as mudanças ocorridas demonstram a existência de uma grande distância entre a situação descrita em 1991 e a conjuntura atual:

(A) "Em alguns momentos, eu posso considerar que, no ano passado, ela teve uma participação decisiva, dando a direção do Projeto. Acho que a comunidade desempenhou esse papel no ano passado. Nos últimos 2 anos, acredito, por conta de mudanças que estavam acontecendo dentro dos CCS, no próprio serviço, a comunidade manteve uma certa clareza na condução do processo, 
e eu acho assim, de uma forma indireta, talvez não assumindo o papel formal de coordenação do programa, mas é, no cotidiano, na prática, quem tava dando a condução do Projeto UNI Londrina tava sendo a comunidade."

(A) "E a atuação da comunidade agora, eu tenho a impressão de que, se você for olhar, nós temos tempos diferentes, como eu já disse anteriormente, mas a comunidade é que tem uma atuação mais sólida."

Existe nessas falas um processo explícito de transição entre a organização incipiente do começo da década de 90 e a organização de condução e de atuação sólida do período atual. Duas vertentes fundamentais devem ser destacadas para melhor compreendê-las: a primeira, o crescimento e consolidação do movimento de base; a segunda, a consolidação da estrutura formal do CONSUL.

As entidades de base, em particular as associações de bairros e de mulheres tanto na região urbana quanto rural, desenvolveram um grande número de atividades, buscando provocar mudanças no perfil do movimento local. Os movimentos de base parecem ter deixado um caráter de vanguarda informal, para assumirem espaços políticos nos níveis local e municipal.

Algumas falas de atores pertencentes aos movimentos de base retratam parte desse processo. Contudo, é preciso que a categoria oposição seja analisada como um recorte nessa etapa de transição organizacional dos movimentos de base. Esse recorte ganha sentido, ao perceber-se como muitas das disputas políticas no município e alguns eventos de ingerência do poder público municipal nas organizações comunitárias transferiram-se de cenários mais amplos para os movimentos de bairros.

(C) "Tinham associações de moradores que não cumpriam o seu papel, aquela coisa muito distante da comunidade. O presidente que só tinha mesmo pretensão de assumir aquele cargo, pra chegar na época das eleições e ser um cabo eleitoral bem remunerado. Daí 
a gente começou a fazer um movimento mais de envolver a comunidade, a participação, criar comissões e tal. A gente acabou criando no bairro o Conselho das Entidades - até porque a gente tinha uma associação de moradores que não fechava com essa questão. (....) Nesse conselho de entidades, a gente conseguia somar a APM, a associação dos pais da creche, comitê da cidadania, várias organizações nossas do bairro - ligadas ao União da Vitória - e dali a gente acabou ganhando as pessoas ligadas a essa organização, a essa visão de movimento, acabou ganhando também a associação de moradores e aí a gente começou a fortalecer mesmo o conselho de entidades, desenvolvendo esse trabalho."

É interessante perceber como o conjunto das atividades realizadas nesses oito anos, com maior ênfase a partir de 96, resultaram em uma base popular mais presente, em processos aparentemente mais democráticos, em momentos de maior interesse coletivo pelas organizações, como é o caso das eleições para o CONSUL:

(C) "E ao final da gestão, o saldo assim para a gente resumir é o seguinte: Na penúltima eleição, onde que nós, eu fui eleito como secretário, 43 entidades tinham direito a voto. Nesta última eleição nós já tínhamos 106 entidades, organizações comunitárias, aptas a participar do processo eleitoral."

Mesmo nas eleições de bairro, onde tradicionalmente as bases populares têm pequena participação, os resultados são bastante expressivos:

(C) "Como prova de organização as eleições do União da Vitória, que é uma das entidades mais forte, né, dizemos assim, claro que dependendo dos membros, né, mas é uma entidade representativa, há tempos atrás votava 300 pessoas, chegou a votar duzentos e poucas pessoas, e com esse trabalho que a gente fez, a própria população, a gente sentiu que resgatou, sentiu a importância, 
porque houve muitas melhoria dentro do bairro, e na última eleição nós teve 2000 eleitor votando."

(C) "A última eleição nossa foi 910 votos a 909, então é uma responsabilidade muito grande. Foram 1856 pessoas que foram as urnas votar pra ter seu representante no bairro. Não é uma entidade formada de um grupo de amigos, é uma entidade aonde vão as urnas e elege, e a responsabilidade da associação de moradores ela é muito mais grande do que qualquer outro grupo que é formado pra representar, porque ela não é apenas um grupo que vai tá representando junto com o bairro, ela é uma entidade eleita que tem suas responsabilidade junto a comunidade."

Embora o CONSUL aglutine atualmente mais de 100 entidades de base $\mathrm{e}^{40}$, merece destaque a vertente que trata de sua organização formal. Em primeiro lugar um grande número de oficinas realizadas pelo CONSUL, bem como as trocas de experiências proporcionadas pelo PROUNI-Londrina, conferiram à entidade a postura de tratar de sua administração de forma estratégica. Em seus documentos pode-se encontrar o seguinte:

Missão do CONSUL:

Acompanhar, avaliar e fiscalizar os serviços de saúde prestados à população pelos órgãos e entidades públicas e privadas, integrantes do Sistema Único de Saúde, no âmbito da região Sul do município, principalmente no acompanhamento político e organizativo dos usuários do sistema.

Objetivos do CONSUL:

a) participar da formulação de estratégias e controlar a execução da política municipal de saúde para a região;

\footnotetext{
${ }^{40}$ Ver no Anexo 10 a relação das entidades componentes do CONSUL.
} 
b) definir junto ao Conselho Municipal de Saúde as prioridades para a região;

c) participar da elaboração do Plano Municipal de Saúde para a região Sul em conjunto com as instituições envolvidas e o Conselho Municipal de Saúde;

d) definir critérios de qualidade para o funcionamento dos serviços de saúde oferecidos pelos órgãos e entidades integrantes do SUS na região Sul do município junto com o Conselho Municipal de Saúde;

e) executar na região Sul a programação e a gestão financeira e orçamentária através do fundo local de saúde, em conjunto com o Conselho Municipal de Saúde e instituições públicas envolvidas;

f) emitir parecer quanto a localização das unidades prestadoras de serviços de saúde, públicos e privados, participantes do SUS, a serem instaladas no âmbito da região Sul em conjunto com o Conselho Municipal de Saúde e instituições envolvidas;

g) formar e capacitar líderes em saúde comunitária;

h) desencadear um processo de formação que amplie o conceito de saúde pública (CONSUL 1998b, p. 7).

Além das intenções presentes na missão e objetivos expostos acima, a concretização de uma estrutura organizacional para o CONSUL também é um fator importante para o respaldo de seu funcionamento. A existência da Conferência de Saúde da Região Sul a cada dois anos, da Assembléia Geral anual e o denominado Sistema Diretivo, que se reúne mensalmente, confere ao movimento um caráter formal interna e externamente ${ }^{41}$ importante.

\footnotetext{
${ }^{41}$ Observar o organograma do CONSUL no Anexo 11.
} 
Parte dessa gestão do CONSUL, cujas observações em campo permitiram chegar à opinião de que existe um processo colegiado de decisão, está refletida na realização de mais duas conferências de saúde na região. A segunda, em janeiro de 1994, com o tema "Análise dos principais problemas de saúde da Região Sul", e a terceira, em setembro de 1996, tendo como objetivos fundamentais o fortalecimento das entidades de base, a articulação dos Conselhos Locais de Saúde da Região, a eleição das prioridades de trabalho e a eleição dos coordenadores dos chamados segmentos (CONSUL 1998b).

Os segmentos são uma das principais características que refletem a crescente organização do movimento nesses últimos anos. Esses segmentos, ao total sete (religioso, mulheres, conselhos locais de saúde, educação, comitês da cidadania, creches e associação de moradores), agrupam entidades com um marcante caráter de mobilização. Conforme o reconhecimento do próprio CONSUL:

A estrutura por segmentos foi a que melhor se adequou ao trabalho comunitário na região Sul, ressalvadas as dificuldades de articulação de alguns segmentos e dos segmentos entre si (CONSUL 1998b, p. 11).

O segmento mulheres foi aquele que apresentou, nos últimos anos, o mais notável desenvolvimento. A partir de uma maior compreensão de seu papel dentro do CONSUL, diagnóstico presente nas três fontes de dados, as organizações de mulheres têm conquistado um grande espaço no cenário político local. Atualmente, é o segmento que mais projetos desenvolve e o que primeiro encontrou, em outras organizações do município, espaço para estender suas discussões e conquistas. Algumas passagens reforçam essas colocações:

(C) "O segmento mulher, que é o segmento que entendeu o papel dele no CONSUL, porque nós reúne uma vez por mês, tiramo nossas diretrizes, e viemos pra dentro da discussão do CONSUL, e os outros segmentos não conseguem fazer isso." 
(C) "A gente passou a fazer uma discussão maior, inclusive dentro das associações de bairros, dentro dos movimentos religiosos, tanto é que o movimento feminino teve um avanço. Nós tínhamos na época 2 ou 3 grupos, hoje me parece que nós temos 14 grupos formados."

(C) "Eu digo que o segmento que mais se sedimentou dentro dessa proposta foi o segmento de mulheres. Eles tomaram aí a idéia, então eles têm se reunido periodicamente, eles têm discutido, eles fazem projetos, eles trocam experiências, de certa forma. E você vê que, hoje, o movimento de mulheres da região Sul é o maior movimento popular da cidade, pelo que eu sinto. Não dá pra você dizer hoje que existe um movimento mais forte. Tanto é que, em Londrina, agora surgiu a União de Mulheres de Londrina, que veio exatamente pra fortalecer essa coisa da região Sul, que é o movimento de mulheres."

(C) "Quando eu falo assim das Mulheres Batalhadoras, é que ela foi a primeira associação, fundada em 91, e hoje a gente tem, só na região Sul, tem 14 associação; na cidade inteira, elas são 36 associação de mulher."

A partir dos resultados obtidos no grupo focal, onde estiveram presentes dois atores ligados aos movimentos de mulheres da zona rural, pôde-se perceber que o trabalho de organização realizado pelo CONSUL tem sido também levado a essa área:

(C) "A associação de mulheres nasceu da necessidade do Patrimônio Selva. Em final de 93, nós tivemos a primeira reunião e nós pegamos a necessidade porque aí tinha a associação de morador mas não desenvolviam trabalhos com mulheres e nem na área social."

Algumas conquistas do segmento puderam ser percebidas, através de análise documental, como o caso da criação da biblioteca virtual, projeto 
financiado pela FWKK a partir da demanda da Associação das Mulheres Batalhadoras do Jardim Franciscato, que elaborou o projeto e obteve o apoio da Fundação. A passagem abaixo, extraída da imprensa, ilustra parte dessa experiência:

A conquista da biblioteca virtual é resultado do trabalho árduo que vem sendo realizado pelas mulheres da região Sul de Londrina, desde a fundação da Associação das Mulheres Batalhadoras do Jardim Franciscato, no final de 91, por mulheres desempregadas. Unidas, estas mulheres têm buscado incansavelmente a melhoria da qualidade de vida dos moradores da zona Sul da cidade. E contam com muitas vitórias. Entre elas estão a implantação de uma unidade de saúde, rede de esgoto, asfalto e uma escola estadual. Lutar pelos nossos direitos é cansativo mas também bastante gratificante a cada conquista, conclui a presidente da entidade (COSTA 1999).

A institucionalização das demandas criadas pelos movimentos de mulheres em Londrina, através da criação do Conselho Municipal dos Direitos da Mulher, também contou com uma forte colaboração do segmento mulheres do CONSUL. Esse reconhecimento também se deu no momento da escolha dos representantes populares neste Conselho, com a vaga ficando com o CONSUL.

(C) "Aí a gente começou levar proposta, a gente fez um fórum em 95, fizemos um fórum de mulher que teve a participação de 400 mulher, e deliberamo criar um órgão maior. E naquele momento da discussão, foi entrando o processo político e não deu. Aí depois nós volto pra discussão e foi aprovado que criasse o conselho municipal da mulher, né. E aí foi criado o conselho municipal agora, com conferência. $E$ as associação pra participar no conselho, elas tinha que tirar, tinha que fazer uma assembléia e tirar delegada da base para mandar pra lá. E eu fui como delegada do CONSUL e fomos disputar a vaga com mais cinco conselhos regional de saúde. Aí nos ficamo com a vaga de titular e o CONSNORTE ficou na suplência." 
Um dos fatos mais recentes, nesse processo de organização, foi a criação do CRESUL, que teve sua discussão iniciada dentro do segmento educação. $\mathrm{Na}$ categoria articulação, o CRESUL esteve também tratado como fruto de um processo que articulou movimentos populares de saúde, escolas, associações de pais e mestres, etc.

(C) "E também, dentro dessas discussões de plenárias, nós fortalecemos também o segmento educação. Foi quando a gente criou o CRESUL, que é o Conselho Regional de Educação Sul. Que ao meu ver, foi uma conquista que, a gente carecia dessa oportunidade na região. E vejo que os outros segmentos irão enveredar por esse caminho."

O reconhecimento do processo de organização dos movimentos populares da região Sul pode também ser encontrado nas falas dos atores dos serviços de saúde:

(S) "A região Sul, até por conta de ser a região que foi escolhida pelo projeto prá sua atuação, ela é a região de Londrina que mais conseguiu se organizar enquanto conselhos locais de saúde. As outras regiões também têm avançado, mas a região Sul em particular. Por conta do projeto, tá ali dentro. Ela conseguiu se organizar melhor, então os conselhos locais já conseguiram se organizar bem melhor, o conselho regional também, então essa ligação é muito boa, nós vemos hoje."

Outro fator que contribuiu muito para a organização do CONSUL e de todas as suas entidades de base foi a compra de uma sede para a entidade em um dos bairros da região, conforme comentado nas análises sobre a autonomia dos movimentos populares. Além disso, o PROUNI viabilizou a aquisição de mobília, materiais de escritório e comunicação, proporcionando ao CONSUL uma estrutura física para fazer frente às crescentes atividades desenvolvidas pela entidade. Além das falas citadas nas análises da articulação, uma importante contribuição está presente em um outro momento: 
(A) "Então eu acho assim: o apoio financeiro é um fator que pesa, tanto pra poder existir a capacitação com as lideranças, quanto na própria organização mesmo da casa, de equipamentos na casa. Eles, enfim eles têm sempre a quem recorrer."

E para concluir a descrição desse período de transição entre 1991 e 1999, é preciso ressaltar ainda que nas Conferências Municipais de Saúde realizadas em 1993 (terceira), em 1995 (quarta) e em 1997 (quinta), pôde ser observada a presença crescente dos movimentos populares da região Sul do município (SANTOS 1998).

Considerando-se, no entanto, as análises da participação, que serão realizadas adiante, conclui-se que nem a marcante organização dos movimentos de saúde, em especial do CONSUL, nem a expressiva participação desses atores nas conferências municipais de saúde, no PROUNI e em outros cenários políticos locais e regionais, foram capazes de garantir ao CONSUL um espaço significativo no Conselho Municipal de Saúde.

Tendo em vista as observações realizadas ao longo do presente ano, parece haver grandes possibilidades da mudança desse cenário, a partir da realização da $6^{\text {a }}$ Conferência Municipal de Saúde.

\subsection{QUEM GANHA COM A PARCERIA ?}

A proposta de estabelecer relações mais horizontais entre os três componentes dos projetos UNI, através da criação de espaços reais de troca, interlocução e transformação mútua é, segundo a FWKK (1997a), a estratégia mais clara para a potencialização das transformações esperadas e desejadas nos três componentes dos projetos $\mathrm{UNI}^{42}$. Como registrado anteriormente, a parceria é

\footnotetext{
${ }^{42}$ Observar no Anexo 12, a figura representando as relações entre os três componentes UNI.
} 
também uma das dimensões que compõem a avaliação do Cluster do Programa UNI.

É preciso destacar que a parceria, cujas dimensões deseja-se analisar aqui, diferencia-se das demais relações de cooperação estabelecidas entre os movimentos populares de saúde da região Sul e outras organizações existentes em Londrina. Essas análises estão apresentadas, ao discutir-se a articulação dos movimentos populares bem como sua cultura política.

A parceria, segundo a FWKK (1997a), é um dos princípios realmente inovadores do Programa UNI e sua importância remonta a algumas das questões discutidas no capítulo 2. Entre elas, a necessidade da participação da comunidade, de maneira mais incisiva, nos projetos IDA, e a necessidade da construção de espaços verdadeiramente democráticos na sociedade latinoamericana. Em atendimento a essas premissas, esperava-se dos componentes dos projetos UNI, a partir de seu início, a mudança de postura e de valores, principalmente em suas inter-relações.

Seria fundamental a quebra de barreiras de comunicação, o rompimento do isolamento habitual das instituições (....) A comunidade passaria a ter um papel ativo tanto nas ações de saúde, como nos processos de investigação, discutindo e participando da identificação de problemas, da definição de prioridades, da construção de soluções e da implementação das ações. Trabalhando em conjunto, dentro e fora dos muros das universidades e unidades de saúde, docentes, estudantes, profissionais dos serviços e comunidade poderiam desenvolver novas modalidades de intervenção e novas práticas de saúde (FWKK 1997a, p. 3).

Há, nesse sentido, avanços e retrocessos na interação entre o CONSUL e os demais componentes do PROUNI-Londrina. Contudo, as observações no campo permitem concluir que existe, ao longo desse processo, uma resultante positiva, como ilustram as falas abaixo: 
(C) "E mais do que isso, é você conseguir trabalhar em parceria. Aí tem muita coisa que a gente vai trabalhar junto. A comunidade tá querendo, o serviço também tá querendo, mas as vezes o que não tava tendo era o contato. A troca de experiência, a troca de informações, aquele momento mesmo. $E$ isso tem dado em propostas, em projetos muito ricos pra ambas as partes."

(C) "Então, o Projeto UNI trabalhando numa linha que só pode melhorar. Agora mesmo tão fazendo aí uma forma de coordenar projeto, ajudar os projeto, de associação de mulheres e vários trabalhos na região que vai ser um contato direto PROUNI e comunidade. Isso deixa as pessoas mais seguras, e eu avalio o PROUNI como uma das coisa mais importantes dentro da região. É lógico por causa da parceria que está tendo com o CONSUL."

(S) "Na parceria, ela já avançou muito de quando começou, hoje já está mais claro o papel dos três componentes então aonde é o meu componente, a minha individualidade e aonde eu intercâmbio com o componente comunidade com o componente educação, com a universidade."

Ao se analisar falas e documentos, percebem-se maiores avanços e entendimentos entre o CONSUL e a academia, enquanto a relação com os serviços de saúde passou por dois momentos com diferenças marcantes. $\mathrm{O}$ primeiro deles refere-se à gestão anterior dos serviços de saúde, identificada pelos atores entrevistados e pelas observações como progressista e democrática, em que as relações entre a comunidade e os serviços de saúde puderam ser reconhecidas como mais fáceis e principalmente mais "francas". O segundo período refere-se à gestão atual, identificada pela maioria dos atores entrevistados como centralizadora e populista, em que as relações de parceria têm sido mais difíceis e, algumas vezes, inexistentes, principalmente no que diz respeito à comunidade e aos serviços de saúde. 
As passagens abaixo sintetizam parcialmente como a atual orientação política e gerencial da ASMS tem dificultado a relação de parceria, o que cria problemas para o bom desenvolvimento do projeto. Têm destaque as colocações feitas, a partir da avaliação das UBS na região Sul que, em momentos anteriores, como revelaram as análises, foram reconhecidas como peças fundamentais no processo de criação de espaços de participação para os movimentos populares da região Sul (BARRIOS 1999). No presente momento, a situação revelada foi outra:

"As coordenadoras de UBS não têm autonomia decisória. O serviço não está viabilizando a participação na base (ações definidas de cima para baixo" (CONSUL 1998b, p. 15).

(S) "Então o projeto hoje tá sendo tocado mais pela universidade e a comunidade, e o tripé mais importante pra prática, pra mudança da prática de ensino, que é a unidade de saúde, nós não temos nada que assegure, nada que ... Isso é uma coisa complicada, que dá pena de ver."

Registra-se também a transferência de coordenadoras de UBS que tinham grande integração com a comunidade, o que fragilizou a construção dos espaços de participação ${ }^{43}$. A fala seguinte, ilustrativa desse processo, mostra a mudança da orientação da ASMS em relação às coordenadoras das UBS.

Em primeiro lugar, a análise da ASMS na administração municipal anterior:

(S) "Aí teve as pré-conferências dos segmentos, de usuários, de prestadores tal, e então foi um momento muito rico no sentido de estar democratizando a informação na $4{ }^{a}$ Conferência. Você discutia o que era o SUS, a estrutura dos serviços, o que o pessoal não tinha idéia. $E$ isso está associado ao processo que estava passando na administração, que era a territorialização, as unidades mais em contato com a população, e havia também um direcionamento da

${ }^{43}$ Diálogo registrado no diário de campo. Neste caso, o ator não teve condições de prosseguir a entrevista, visivelmente incomodado por tratar dessas questões. 
administração de que o coordenador deveria puxar essa discussão nas unidades."

Em segundo, a análise da ASMS na administração atual:

(S) "E foi interessante que agora chegou na $5^{\text {a }}$ Conferência e o pessoal tava acostumado com a conferência anterior, onde eles tinham a orientação de puxar pré-conferência, discutir na unidade. Chegou na $5^{\text {a }}$ Conferência. Vinham e me perguntavam: e agora, o que que a gente faz ? É pra puxar conferência ou não é (....) E agora, o que eu faço ? Qual é a ordem ?"

Como o parceiro serviços de saúde não é apenas representado pelo nível central, as organizações comunitárias, e mesmo a academia, têm procurado preservar os espaços de colaboração na base da rede de saúde. A dificuldade de sustentar essas relações é, contudo, muito grande, tendo em vista a orientação dada pela ASMS às coordenadoras de UBS, revelada na fala acima.

Já as relações com o componente academia parecem ter ocorrido de maneira mais fácil, ao longo dos últimos anos. Alguns atores dos movimentos populares de saúde apontam a parceria como um ponto de apoio importante nas situações onde eles foram colocados frente aos demais componentes do PROUNI-Londrina.

(C) "E eu consegui, através da participação na coordenação do Projeto, a gente ponha respeito dentro lá da universidade hoje. Eles hoje respeita a gente como parceiro."

Entretanto, a parceria é vista pelos atores como uma construção sobre três pilares, onde o atraso ou fragilização de um deles compromete todo o trabalho. Neste caso, algumas falas ressaltam as dificuldades em "acertar o passo" dos três componentes:

(C) "Eu acho que o parceiro, ele só consegue fazer os custo de um valor, quando você valoriza o teu parceiro igual a você, onde você 
consegue fechar essas discussão do que que é. Se você é três parceiro, se você tem um que tá mancando numa perna, como é que você vai dizer que tá dando certo, se os três não vai chegar junto ?"

(C) "O que nós vamos fazer junto: Universidade, comunidade, secretaria municipal de saúde ? Pode ser que o dinheiro fica tudo alocado lá na universidade, mas o que é as ações que nós vamo planejar junto ?"

Com isso foi possível identificar algumas questões que expõem certas fragilidades da parceria e a existência de descompassos entre os três componentes. Alguns atores destacaram o fato de que algumas negociações sobre a chamada "porta dupla" no Hospital Universitário em Londrina têm sido conduzidas sem qualquer inserção da comunidade:

(C) "Você tem aí uma discussão pra todas as ações, mas, por outro lado, você tá vendo aí uma proposta de se cobrar serviço no hospital universitário, de abrir espaço pra cobrança de serviços. Como que é isso ? Não dá pra entender, não houve uma discussão. Inclusive com a gente, que tá aí como parceiro. Que parceria é essa, que não senta na mesa pra discutir, não coloca sua visão ?"

(C) "Nesse momento que senta a universidade, o serviço e a comunidade pra discutir o caminho a ser tomado, isso daí é que é relevante. Embora isso não venha ocorrendo hoje por parte dos serviços de saúde, e a própria universidade nesse caso do hospital."

(C) "Eu só acho que a academia, ela tem o nome de parceiro, mas eles ainda vêem a comunidade muito distante, tipo assim: $O$ doutor sou eu, quem sabe sou eu. A gente percebe isso ainda no dia-adia, apesar de todas as barreiras que foram rompidas."

Uma vez que a parceria é, para o Programa UNI, um fenômeno dinâmico onde permanentemente se reconhecem diferenças, tomando-as em conta para a construção de objetivos comuns, é preciso ressaltar que sistematicamente os 
componentes do PROUNI-Londrina têm encontrado maneiras de prosseguir no desenvolvimento do Projeto.

Percorrendo-se as discussões sobre cultura política e, principalmente, ao se discutir a oposição, é possível identificar mais alguns fatores que contribuem para ampliar a compreensão sobre esta categoria.

\subsection{CULTURA POLÍTICA: CONSTRUINDO UM PACTO POPULAR}

Para uma melhor compreensão desta categoria de análise, entendeu-se que se deveria dividi-la em três vertentes diferentes:

a) descrever e analisar as relações políticas entre os movimentos populares, demais movimentos de saúde e outras organizações locais;

b) descrever algumas práticas políticas e seus efeitos para os movimentos;

c) refletir sobre a construção de uma nova cultura política para os movimentos populares de saúde na região Sul de Londrina que, metaforicamente, poderia ser tratada como um processo de amadurecimento das lideranças e organizações em sua atuação política.

Deve-se registrar que, nas dimensões que se seguem, essas três vertentes estão intimamente relacionadas.

\subsubsection{Relações Políticas}

A intenção aqui é demonstrar de que forma ocorrem as relações entre o CONSUL, seus movimentos de base e os demais movimentos populares no 
município de Londrina, com ênfase para os demais conselhos de saúde regionais (CONSNORTE, CONSLESTE, CONSOESTE e CONSCENTRO), bem como com o Conselho Municipal de Saúde.

Os demais conselhos de saúde regionais em Londrina apresentam uma estrutura de caráter nitidamente menos orgânico do que o CONSUL, ou seja, suas estruturas estão enraizadas, principalmente, sobre os conselhos locais de saúde das UBS da região de interesse e, historicamente, sua fundação esteve mais ligada aos espaços criados pelo SUS do que especificamente a lutas populares por melhores condições de vida e saúde.

Os demais conselhos regionais possuem, ao contrário do CONSUL, uma participação menos expressiva das entidades de base, tais como as associações de moradores e pastorais da Igreja, embora essas entidades estejam presentes em boa parte dos conselhos locais das UBS das regiões correspondentes.

Assim, o aspecto que mais parece diferenciar o CONSUL dos demais conselhos de saúde parece ser sua estrutura orgânica construída a partir das demandas de movimentos e lideranças populares organizadas, sem necessariamente representar um conjunto de organizações jurídico-institucionais do aparelho de Estado, ou seja, os conselhos de saúde das UBS.

Essa característica parece ter conferido ao CONSUL maior liberdade e autonomia para o questionamento de políticas públicas e para a formulação de suas próprias políticas. Ao servir como um grande "guarda-chuva"44 para centenas de organizações de base, o CONSUL passou a definir suas linhas políticas, não apenas sobre discussões restritas aos conselhos de saúde - muitas vezes aspectos puramente gerenciais - mas $\operatorname{sim}$ a tratar de interesses muito mais amplos, como a habitação, o transporte, a alimentação, o emprego, o saneamento básico, a educação, a violência contra a mulher, etc.

\footnotetext{
${ }^{44}$ Expressão registrada no diário de campo, tendo sido utilizada por um membro do CONSUL durante o trabalho de campo.
} 
Nesse sentido, o CONSUL deixou de organizar sua agenda a partir das demandas dos conselhos locais de saúde, mas ao contrário, passou a inserir essas discussões nas agendas das organizações de base. As falas dos atores dos movimentos das demais regiões ilustram parte dessas considerações:

(C) "O CONSCENTRO surgiu a partir de uma necessidade de liderança na saúde aqui nesta região do centro da cidade. Então, compõe três unidades básicas de saúde, né, que é a Vila Nova, o Centro Social Urbano e o José Belinati. Então como é centro assim, o pessoal achou que não precisava, mas aí as coordenadoras dos centros precisava, aí eu, como eu sou muito conhecida na região, formaram o CONSCENTRO né, esse conselho."

(C) "O CONSCENTRO, como eu disse, é composto por essas três unidades de saúde, né. E quando a gente formou, nós preferimos ficar unidos, as três unidades, e agora nós vamos separar, e vamos fazer três conselhos locais. Nós não temos os conselhos locais. Então eu já comecei a formar."

(C) "O CONSLESTE é formado pelo Conselho de Saúde do Novo Amparo, o Conselho de Saúde do Mister Thomas o Conselho de Saúde do Lindóia, o Conselho de Saúde do Pátio das Indústrias Leves ali perto do Grêmio ali, pelo conselho de saúde da Vila Casoni pelo conselho de saúde da Vila da Fraternidade, pelo conselho de saúde da Vila Ricardo, pelo conselho de saúde do Jardim Marabá, e pelo conselho de saúde do Ernani Moura Lima. Agora em maio deve ser inaugurado o posto do Arlindo Boasi, um posto que vai funcionar 24 horas, como uma referência para a região. E neste posto inclusive já temos até os elementos para formar esse conselho."

(C) "São 7 postos de saúde que nos conselhos locais fazem uma reunião por mês, para discutir a parte do bairro né. A partir dessa reunião, é feita uma reunião do CONSOESTE também, na qual a gente convida todas as unidades básicas, todos os coordenadores, 
o pessoal dos conselhos, que se reúne numa reunião geral. Que seriam em torno aí de 7 unidades básicas né, que abrange, gira em torno aí de 33 bairros."

Estas diferenças entre a composição do CONSUL e dos demais conselhos locais, resultou em alguns fatores que têm dificultado as relações entre os mesmos. Tais fatores têm sido alimentados também pela participação do CONSUL no PROUNI-Londrina, o que tem gerado um certo distanciamento dos demais conselhos de saúde.

(C) "O CONSUL é o mais velho, e parece que ele começou assim na época das vacas gordas, então eles têm recurso. Agora nós do CONSCENTRO, CONSLESTE, CONSNORTE e CONSOESTE, a gente até agora não conseguimos nada, porque diz que o PROUNI ajuda bastante, mas nós ainda não conseguimos esta ajuda."

(C) "Hoje nós vemos lá na região Sul um número enorme de conselhos, associações, entidades, que são fruto deste Projeto UNI. Ele despertou na comunidade a necessidade de se unir, de partir em grupo. Eu sempre falo nas reuniões, que na ocasião, lendo um livro descobri que nos EUA, de cada 10 habitantes seis pertencem a alguma associação, alguma entidade, então isso é muito bom. Aqui nossa maior dificuldade é reunir 20 pessoas numa reunião. $O$ pessoal não quer saber de nada, é muito acomodado, e com o surgimento do Projeto UNI a zona Sul se politizou. A realidade é essa. Além do alcance social que o próprio Projeto trouxe, a zona Sul ficou mais politizada, porque eles viram que quanto mais organizada maiores seriam as condições de conseguir os recursos."

(C) "O Projeto UNI é, a gente sabe que o CONSUL conseguiu né, o CONSUL e a UEL, e a gente tá tentando trazer, aumentar esse projeto. Ou seria, do CONSUL passar pros outros conselho, tipo um pouco de verba, pra que a gente possa fazer um trabalho melhor. Porque hoje o trabalho que a gente faz é tudo na base de pedir né, um apoio daqui, um patrocínio dali. E se realmente esse projeto 
viesse a se estender pra outros conselhos, seria uma excelente, daria pra gente fazer um trabalho melhor junto à comunidade."

Além da distância criada pelos fatores expostos, foi também percebido que à medida que as lideranças da região Sul vão ganhando em conhecimento e capacidade política, sua visão sobre os demais conselhos torna-se cada vez mais crítica, contribuindo para um maior afastamento entre os mesmos.

(C) "Olha, eles participa, de toda as reunião do conselho eles tão lá, mas tem conselho criado, não tem muita discussão, não tem muito envolvimento de liderança, né, então sempre é o mesmo cara que tuda vida tá lá, em tudo lugar que se vai tem um só, desses regional, eles não conseguem ter uma discussão, ter um envolvimento com as outras, criar um pool de discussão com as outras entidades como é o CONSUL."

(C) “Então, o CONSUL, por essa questão do projeto, ele ficou assim com um relacionamento difícil com os demais conselhos. O que é o que acabam dizendo: o CONSUL tem dinheiro e não reparte com outros conselho."

Além das observações registradas acima, as relações políticas têm se tornado mais difíceis à medida que lideranças ligadas aos demais conselhos regionais seguem alimentando discussões e mesmo procurando criar novas instituições que possam obter recursos do PROUNI-Londrina ou da FWKK. A opinião manifestada por um dos atores ligados ao CONSUL enfatiza a diferença em relação aos demais conselhos:

(C) "Primeiro, tem que se pensar em ter um conselho com organização, para mobilizar a comunidade, pra levar as reivindicações, a luta e tal, conscientizar, discutir os problemas e tal, e a partir disso quem sabe elaborar projetos; alguém que possa vir financiar o CONSUL, ser um co-irmão, apoiar, ajudar no que for possível e tal. E não foi isso que foi valorizado no momento das primeiras conferências e tal." 


\subsubsection{Práticas Políticas}

As práticas políticas podem ser entendidas como as formas através das quais os movimentos populares viabilizam a mobilização necessária às suas lutas, bem como atingem os objetivos definidos para suas organizações de base e para - CONSUL. Pode-se, portanto, destacar algumas práticas políticas comuns aos movimentos populares de saúde: mobilizações através de manifestações públicas, elaboração de atividades que captem mais participantes para o movimento, atividades de geração de renda, elaboração de panfletos e jornais, etc.

Quanto à mobilização, algumas passagens ilustram o fenômeno:

(C) "Se não dá pra resolver em reunião, não dá pra buscar uma solução junto, a gente busca, quando é uma questão pública com o prefeito, secretário, tal, a gente reforça com outras entidades da região e vamos falar com o secretário. E já aconteceu vezes de falar até com o governador. A gente acredita. A experiência diz que funciona muito melhor com mais pessoas trabalhando."

Região Sul Saúde Urgente - a saúde como a gente quer. Venha debater a crise da saúde e a situação do Hospital da Zona Sul. Participe (....) Uma atividade deliberada pelo Conselho Diretor do CONSUL. ${ }^{45}$

Dentre as atividades desenvolvidas pelas organizações, têm destaque os trabalhos das associações de mulheres. Além da criação da Biblioteca Virtual, abordada nas análises da organização, outras questões devem ser lembradas:

(C) "E essas associação de mulher, elas têm assim um perfil diferente (....) cada associação, tem o trabalho aí com as mulheres, umas com 100, outras com 90 mulher, outras até com menos, outras assim, visita direto, que nem nas Batalhadoras, nós tem

\footnotetext{
${ }^{45}$ Panfleto reproduzido no Anexo 13.
} 
cerca de 700 famílias que a gente faz o trabalho, de visita, de controle social, de saúde pública, levantando a necessidade da comunidade."

(C) "Quando você vê essa pessoa que tá no tear ${ }^{46}$, isso aqui é pessoas que a gente recuperou, as associação recuperou, quando ela não tinha mais auto-estímulo. Vivia só no posto de saúde, tomando carmante e a gente trouxe pra dentro das associação pra fazer um trabalho, com elas. E essa senhora aqui hoje já é monitora, ela já deu aula aqui no norte do Paraná inteiro."

(C) "Isso é um projeto que deu grandes resultado e a gente teve uma participação de 1500 mulher. Nós fazia esses trabalho nos sábado, nos posto de saúde. E aí eu acho que um projeto que foi mais integrado, porque participou o aluno, a comunidade e o serviço municipal de saúde.“

Um aspecto que deve aqui ser destacado é o fato de que algumas práticas políticas desenvolvidas pelas associações de mulheres funcionam como estratégias para a ampliação da capacidade de luta do movimento incrementando a participação - e servindo ainda para que algumas famílias encontrem alternativas de geração de renda para enfrentar as dificuldades socioeconômicas.

Isso pode ser identificado no momento em que uma associação, como por exemplo a Associação das Mulheres Batalhadoras do Jardim Fransciscato, desenvolve oficinas de corte e costura para mulheres da região, mantendo nessas oficinas, em meio ao aprendizado técnico, as discussões políticas dos movimentos populares.

Além disso, os diálogos e as observações realizadas no campo puderam revelar que uma grande preocupação do segmento mulheres do CONSUL é

\footnotetext{
${ }^{46}$ Mostra matéria com ilustrações publicadas no jornal O Estado do Paraná. Ver COSTA (1999).
} 
resgatar pessoas que estejam afastadas do convívio comunitário, trazendo-as para as oficinas de geração de renda.

Pôde-se identificar um exemplo marcante dessa situação, onde uma senhora desempregada, vivendo sob efeitos de medicamentos antidepressivos, conseguiu deixar essa condição, através da participação em oficinas de geração de renda, tornando-se professora das turmas atuais e ensinando até mesmo em outras associações comunitárias de municípios vizinhos a Londrina ${ }^{47}$.

\subsubsection{Das Reivindicações às Propostas}

Esta análise pretende identificar a transição ocorrida entre a postura reivindicatória dos movimentos populares de saúde, no início do PROUNI, e a postura propositiva atual. Para isso, foi preciso balizar várias dimensões envolvidas nesse processo, a maioria das quais está presente nas demais categorias discutidas, como a capacitação, a organização, a parceria, as práticas políticas e a articulação.

A idéia que se pretende apresentar é que essa transição só aconteceu quando os movimentos populares foram se incorporando à dinâmica do projeto, tomando consciência de seu papel ativo e co-responsável nas relações entre os componentes UNI. A transição entre o ser (objeto) e o agir (sujeito) é o que se apresenta nas falas e discussões colocadas a seguir. Este processo de "construção de sujeitos" parece ter sido uma das conquistas mais marcantes da comunidade, a partir do PROUNI.

Em primeiro lugar, é preciso observar, no projeto escrito em 1992, parte da visão do grupo de trabalho sobre a organização da comunidade. Encontra-se então a seguinte fala sobre a mobilização popular:

\footnotetext{
${ }^{47}$ Fato relatado durante o trabalho de campo.
} 
Esta mobilização foi e está sendo construída em torno das necessidades de saúde mais prementes da população, tais como: construção de mais postos de saúde, ampliação de horário e de serviços em todos os postos de saúde da região, ampliação dos leitos hospitalares, aumento da oferta de medicamentos, ampliação do horário de atendimento odontológico, saneamento básico na região e outros (UEL 1992, p. 7).

No entanto, a partir das observações feitas em campo e das análises de entrevistas e documentos, é possível perceber grandes mudanças em relação ao estágio inicial. Estas mudanças se devem a vários processos paralelos, destacando-se as seguintes: a contribuição das relações de parceria desenvolvidas no PROUNI; a possibilidade de intercâmbio entre as comunidades dos demais projetos na América Latina; a possibilidade do acesso a recursos financeiros; o desenvolvimento constante de atividades de capacitação e, por fim, a utilização de instrumentos estratégicos tais como o planejamento e avaliação pelas organizações populares, o que deu mais consistência a suas mobilizações e lutas.

Além disso, é preciso também mencionar a contribuição do PROUNI em dois aspectos estruturais fundamentais para a região. Primeiramente, o investimento realizado pelo PROUNI na adequação, construção e reformas de alguns serviços de saúde na região Sul, assim como na aquisição de equipamentos médico-hospitalares. Em segundo lugar, a disposição do serviço municipal de saúde em provocar modificações tanto na estrutura física dos serviços da região, quanto na gestão dos serviços de saúde que pôde ser percebido principalmente na gestão municipal anterior.

As estratégias de mudança nos serviços de saúde dizem respeito à capacitação dos gerentes das unidades, ao apoio deliberado à estruturação dos conselhos de saúde, à implantação do orçamento participativo - que não se restringiu ao setor saúde -, às oficinas de planejamento estratégico desenvolvidas em algumas UBS (BARRIOS 1999), à utilização do geoprocessamento nas ações 
de vigilância à saúde, à informatização do sistema de prontuários, à constante capacitação de profissionais de saúde, entre outros.

Esse conjunto de realizações resultou em melhorias nas condições dos equipamentos de saúde locais que, até então, eram demandas populacionais não supridas. Uma das falas retrata a forma como se deu parte dessas conquistas:

(S) "De que maneira ela interfere de fato na formulação das políticas? Bom, eu digo que, no que se refere à reivindicação por atenção à saúde não suprida, ela tem importância inquestionável. Por exemplo, uma unidade de saúde que não existe, não tem profissionais de saúde, algo que a população de lá necessita, (....) atenção àquela demanda reprimida existente naquele local, por aquele profissional. Ela consegue se organizar e pressionar o poder público: isso é uma influência importante em formulação de política e se refere a resolver a demanda reprimida na área de assistência, área de atenção à saúde. Isso tem ocorrido, sem dúvida que tem ocorrido."

Essas conquistas proporcionaram aos movimentos populares locais a oportunidade de romper a barreira das reivindicações, alcançando um nível mais abstrato de pensar e agir em saúde, inclusive na discussão de novos modelos assistenciais, como o PID e o PSF. O fruto dessas modificações, ainda que muito incipiente, pode ser percebido nas falas abaixo:

(A) "Eu acho que a comunidade da região Sul, ela tem uma característica que além de lutar e defender seus direitos e ter posições, defende suas posições, claro, de forma clara e efetiva. Ela não tá em cima de uma forma só reivindicativa, mas ela, como eu já disse, ela tem posições, ela se propõe a sentar junto pra resolver, e tem propostas, numa atitude muito mais madura e consciente do que aquela só de bater panela, e não quero saber, e reivindicar seus direitos. Não que eles tenham deixado de lutar por seus direitos, eles mantêm uma luta, mas muito mais efetiva e mais madura." 
(S) "Nesse processo, o simples fato de ter uma pessoa que mora no Patrimônio Selva e chega lá na Universidade, como aconteceu outro dia, pra discutir o projeto com uma visão ampliada, de participação, que ela tem o direito de opinar sobre o projeto, leva a uma conclusão, pelo menos da minha parte, que houve uma consolidação do CONSUL."

(S) "Tão deixando de ter aquela posição de espectador ou de cobrador, mas tá tendo um papel mais pró-ativo em vez de um papel mais passivo, só de cobrança, que foi o papel do passado."

A contribuição da academia, principalmente através de algumas atividades extramuros, também contribuiu para que as reivindicações perdessem espaço para outras formas de luta e conquista:

(A) “O PEPPIN, por exemplo, o pessoal das associações de moradores estão lá juntos, querendo discutir juntos o problema a ser estudado (....) e nas outras regiões você tem que ir atrás...e lá não, eles já sabem o que é o PEPPIN, o que vai trabalhar (....) têm uma proposta (...) nós gostaríamos de que trabalhasse esse ano esse problema aqui na nossa região."

Quanto aos CLS nas UBS, apesar das atuais dificuldades criadas pela ASMS, conforme anteriormente discutido, uma lógica de cooperação também foi inserida entre os movimentos e as coordenações das unidades. A incorporação da idéia de agir (sujeito) junto aos problemas de saúde da região está presente na transcrição seguinte:

(C) "Os CLS trabalha em cima da área de fiscalização dos próprio profissional que trabalha, forma de atendimento à população. Mas nós aqui, no nosso modo de ver, ele tem uma questão mais específica, uma questão mais ainda importante do que fiscalizar. Trabalhar junto com a coordenadora do posto, o médico e enfermeira e buscar junto solução para as coisas." 
(C) "E hoje não, hoje a gente vê um diálogo estabelecido, muitas iniciativas pra buscar propostas conjuntas, intersetorias e tal, partir da comunidade. E isso pra mim, até assim, me deixa em contentamento, porque, como eu disse, eu sempre achei que a gente não podia ficar só no reivindicatório. Batendo panela tal, nós quer, nós precisa e tal, mas e daí? O que fazer pra viabilizar isso ? Então, isso é importante. E a maioria dos projetos que a gente desenvolve é sempre nesse sentido, de desenvolver, de capacitar e de crescer."

Os próprio atores dos movimentos populares demonstram perceber a transição entre determinadas posturas das lideranças anteriores, que iniciaram o trabalho no PROUNI, e as orientações políticas atuais:

(C) "A $x^{48}$ tinha uma visão de batalha mas não tinha uma visão de proposta. Ela ia lá e falava assim: Ó, eu quero 5 mil pra fazer isso. E dava murro na mesa, mas ela não tinha um projeto, uma proposta. Então era muito tumultuado o trabalho."

\subsubsection{Cultura Política}

A construção de uma cultura política dos movimentos populares na região Sul de Londrina é o resultado do conjunto de atividades que vêm sendo realizadas no Projeto UNI, ao longo da década de 90. As dimensões que merecem destaque nessa construção aparecem, em alguns momentos, nas falas que as demonstram:

1. A responsabilidade das lideranças.

(C) "Mas é aquele velho ditado. Pra fazer alguma coisa pra um bairro, pra uma região, não precisa ter cargo, precisa de proposta de

\footnotetext{
${ }^{48}$ Nome omitido
} 
trabalho, uma linha para trabalhar, e aí você vai tá fazendo alguma coisa, você vai tá envolvido em alguma coisa, de qualquer forma."

(C) "O pessoal que ganhou a eleição aqui, a gente tem uma dificuldade pra trabalhar com eles. Eu já conversei com todos eles aqui em casa pra falar como a gente trabalhava e o que a gente quer fazer com eles. A gente quer trabalhar junto com eles, quer ajudar, quer que eles cresça porque se eles não crescerem, não consegui fazer um bom trabalho não é ruim só pra eles."

2. A prioridade em formar atores conscientes de seus direitos e das questões políticas e sociais envolvidas nas lutas comunitárias.

(C) "Porque nós, trabalhando na área de conscientização dos moradores, na importância que tem a participação, no conhecimento em todas as áreas profissionais que tem dentro da nossa cidade, até do Estado."

(C) "Porque durante todo esse processo de ditadura e tal, a população não quis saber de participar de nada. Foi até enfiado mesmo, na cabeça das pessoas, que era perda de tempo se envolver, se preocupar com o bairro, com a rua, essa coisa toda."

(C) "Então, a questão que tá colocada é que pra quem tá no poder, é um problema sério comunidade organizada, que cobra seus direitos e tal. A gente, vamos dizer, estamos nadando contra a correnteza. Ao mesmo tempo em que existe aí um pensamento nacional agora, de que está tendo alguns questionamentos, mas de cada vez o poder público investir menos nas áreas sociais, e cada um se vira por si. E ao mesmo tempo tá acontecendo a comunidade se organizar, exigir dos representantes trabalho, recursos, financiamento, investimento. Aí fica uma situação complicada."

3. A articulação das lutas locais com a temática das lutas populares mais amplas do País. 
(C) "Porque hoje a gente vê: a grande doença, na questão de saúde, é a ausência de emprego."

(C) "E outra questão também é a consciência, que elas são cidadã, elas têm direito, em qualquer lugar, igual a outro."

4. A articulação entre visão local e visão global dos movimentos para a elaboração das ações.

5. A criação de espaços democráticos para a ação dos movimentos de base dentro do CONSUL.

6. O conhecimento de que à medida que o movimento se desenvolve e se projeta politicamente, forças políticas externas começam a agir no sentido de romper a estrutura conquistada pelo movimento.

(C) "Infelizmente tem pessoas municiando, alimentando esse tipo de rivalidade, de conflito, que não soma para nós enquanto movimento, enquanto organizações comunitárias, populares."

(C) "O conflito não deixa a coisa avançar, porque enquanto a gente estiver neste embate, gastando energia, a gente não vai tá elaborando projetos, propostas, avançando nas discussões, tendo uma análise mais profunda da conjuntura, uma crise como essa que esta passando o mundo, o Brasil e tal."

7. A necessidade de aprofundar as relações de parceria no PROUNI-Londrina e as relações políticas no município.

(C) "Então se a gente souber aproveitar isso, isso sendo repassado cada vez mais, pra mais pessoas, a gente vai chegar aí num nível de realmente o povo poder exercer o controle social. Porque a gente tá muito aquém. Não adianta a constituição garantir e tal. Mas, se a gente não tiver esse tipo de apoio, essas parcerias, a gente não vai tá exercitando, pra poder chegar a esse nível. Aqui se exerce o controle." 
(C) "Mas hoje não, as associação não, elas estão intervindo mesmo nas políticas públicas, tanto a questão da educação, a saúde. É pra interferir, pra buscar um entendimento entre poder público e a sociedade."

8. A valorização de posturas políticas independentes dos demais componentes UNI e dos partidos e forças políticas locais.

9. A visão dos próprios atores dos movimentos populares de que o trabalho tem tido grande impacto nas lutas populares.

(C) "Então, não é toda a comunidade, mas nós tem hoje ali na região mais de 30 pessoa que não aceita mais, tão já é um avanço, não é uma pessoa sozinha que tá lutando prá...E assim, consegue discutir, elas vai lá, elas brigam com prefeito, elas brigou com o major, o major mandou elas cala a boca, elas falou: "cala a boca por quê ? O senhor cala a boca primeiro, depois nós cala". De primeiro, aonde que essas pessoa discutia ao menos com a polícia ? Não discutia. Essa visão que não tem uma maior do que o outro, já tem bastante gente que já consegue e elas marca reunião, elas vai lá e fala com o reitor."

10. O crescimento da visão crítica em relação às políticas públicas.

(C) "Porque as crianças estudam, então elas tão vivendo tudo isso lá. Tem um colégio, o filho tem que passar a BR. Porque o governo vem, fez a BR e jogou o conjunto deles lá. Os maus planejamento né, que os político, os prefeito não planeja... Onde fica melhor o conjunto, então eles já fazia onde dá na cabeça. Um terreninho vazio já põe lá um bloco de casa. E a condição dessas pessoa depois ? Dirigir o posto de saúde, dirigir uma escola."

(C) "E minha grande meta agora de trabalho é a questão agora da educação política das liderança. Voltar a discutir o que é política, porque a visão aí, hoje, como a gente consegue discutir a visão de 
uma saúde, uma educação, uma coisa mais ampla, discutir a política dentro desse conceito, o que que é política."

(C) "Não tem visão de cidadão, se as pessoa não têm uma visão política."

\subsection{GRUPOS DE OPOSIÇÃO: A LUTA PELO CONTROLE SOCIAL}

O conflito entre os movimentos populares de saúde e outros atores sociais foi um dos temas mais freqüentemente apresentados pelos atores. Em alguns momentos, tornou-se muito difícil a separação das categorias de análise, visto que a oposição aparecia envolvida nas colocações sobre a autonomia, a cultura política, a parceria, etc.

A partir das informações obtidas em campo, principalmente através das entrevistas com os informantes-chave, o maior destaque à oposição deu-se em relação ao poder executivo, incluindo a ASMS e o próprio prefeito, e ao poder legislativo municipal, essencialmente à base de sustentação do prefeito.

Um primeiro aspecto a ser destacado ocorre em relação ao pequeno apoio recebido pelo CMS do atual secretário de saúde do município. Segundo alguns atores, o ponto sempre questionado é a "produtividade" do Conselho:

(C) “Já ouvi do próprio secretário municipal de saúde que o conselho é improdutivo. Mas por que é improdutivo ? Porque a pessoa que tá lá não tem qualificação nenhuma pra conduzir uma reunião."

Em decorrência da pouca atenção e apoio dados ao CMS que, conforme se discute na análise da participação, apresenta uma composição que é vista pelos movimentos populares de saúde como inadequada, o conselho tem funcionado 
apenas como um instrumento que referenda as idéias que emanam da estrutura central da ASMS.

(C) "Sempre no CMS tem acontecido o que o executivo quer."

A oposição pode ser percebida ainda a partir da falta de percepção da ASMS às reivindicações dos representantes populares no CMS. Sobre isso, vale a pena observar as opiniões contraditórias entre comunidade e serviços em relação à extensão das reuniões do Conselho:

(S) "Ele é um conselho muito forte, muito bem articulado, organizado e discute seriamente as políticas de saúde, é um fórum que discute mesmo, tanto que as nossas reuniões começa as 19,19h30 e muitas vezes seguiu até meia-noite, uma hora da manhã. É um conselho que, enquanto ele não discutir, não esgotar o assunto e votar e caminhar, ele não deixa passar superficialmente."

(C) "As pautas são muito extensas. Quando você tem algumas coisa de interesse popular pra discutir, isso acaba passando da meianoite. É hora do pessoal se dirigir pra suas casa de ônibus aí. E quem vai embora? O ônibus só corre até meia-noite, então acaba esvaziando a plenária. E acaba sendo transferido pra o mês seguinte, enfim, sempre sendo levado. E nós participamos como ouvinte e não podemos emitir opinião."

Além dessas considerações a respeito do CMS, a oposição mais aberta tem se dado nos processos de eleição das organizações populares da região Sul, como as associações de bairro e associações de mulheres:

(C) "De repente, a gente já sentiu, por exemplo, o grupo do vereador $x$, o grupo do vereador $y^{49}$, entendeu, já ampliou esse leque. A discussão não é mais só comunitária, passou a ser também política."

\footnotetext{
${ }^{49}$ Nomes omitidos
} 
Segundo os depoimentos, a perspectiva do surgimento de candidaturas populares ao legislativo tem incomodado alguns atuais vereadores, motivado-os a interferir nas organizações da região Sul:

(C) "E aí tem a questão de vereadores que acham que daqui, desse movimento, pode surgir uma candidatura que venha roubar voto deles na próxima eleição."

(C) "Agora, como eles acordaram que as associações de mulheres têm força também e elas tão inseridas em projetos e nessa discussão, então a disputa pelo poder está indo nas associação de mulher."

Em relação ao prefeito, os depoimentos demonstram que o receio principal é a perda de popularidade à medida que manifestações populares comecem a surgir na região Sul, expondo à mídia local as deficiências da administração atual.

(C) "É um prefeito que não quer que fica aí, moradores indo lá protestar ou protestando mesmo aqui na região (....) Isso acaba tendo uma repercussão na mídia e tal e pra ele não é bom. $E$ aí isso foi que foi, o que deu, na questão da eleição."

\subsection{PARTICIPAÇÃO}

A partir da criação dos conselhos de saúde na dinâmica do SUS no Brasil, o tema da participação tem ganho importância significativa nos discursos que tratam de sua implantação e implementação, com fins de alcançar as doutrinas expressas pela Constituição Federal: universalidade, eqüidade e integralidade.

Como afirma SOUZA (1993), a participação é um processo existencial concreto, produzido na dinâmica da sociedade e que se expressa na própria dinâmica dos diversos segmentos da população. Assim, embora os discursos 
continuem cada vez mais carregados com a necessidade da ampliação do controle das políticas de saúde, através da participação institucionalizada nos conselhos, a percepção da realidade dos serviços pelas massas populares continua carente de um processo legitimamente democrático.

A análise da participação popular em Londrina, envolvendo tanto as relações nos Conselhos de Saúde regionais, quanto no CMS, revela mais algumas questões importantes para o trabalho. Em particular, demonstra o grau de fragilidade, o pouco diálogo e o distanciamento que têm marcado as relações entre a comunidade e a ASMS, no momento atual.

Quanto ao CMS, complementando as análises realizadas quanto à categoria oposição, onde o CMS pôde ser identificado como um instrumento de manutenção de um poder político concentrado na estrutura da ASMS, as falas ilustram as deficiências mais amplamente conhecidas do CMS:

(C) "A gente sente, eu sinto pessoalmente, que essas conferências são só pró-forma, pra dizer olha: o município $\mathrm{x}$ realiza suas conferências, mas, na prática, a coisa é empurrada goela abaixo."

(C) "Ta aí o caso do PAl (Pronto Atendimento Infantil) que não foi aprovado em nenhuma pré-conferência, não foi aprovado na conferência municipal, mas foi aprovado no CMS, que era contra a construção do PAl."

(C) "Bom, disso aí desdobra a questão do CMS. Porque o CMS, ele não contempla os usuários e isso vem sendo levantado na $3^{\text {a }}$ conferência, na $4^{a}$ conferência, na $5^{\mathrm{a}}$ conferência."

A mesma postura, aparentemente "pseudo" democrática, aparece em relação aos Conselhos de Saúde das UBS:

(C) "Se for um Conselho local bom, é aquele que aceita tudo que o secretário e os seus subordinados lá dizem que é bom pro posto. Se 
for um Conselho que quer discutir, quer debater, quer propor, já não é um Conselho que funciona, bom 100\%."

Um aspecto interessante é que, apesar de toda organização alcançada pelo CONSUL, ainda não se viabilizou a vaga de conselheiro no CMS para esta organização, embora conferências municipais anteriores tenham sempre aprovado mudanças na composição do Conselho, o que nunca se efetivou na Câmara de Vereadores:

(C) "Mas participar como conselheiro a gente ainda não conseguiu. Apesar que já foi aprovado em duas conferência municipal de saúde, não conseguimos ainda, e não é tanto pela secretaria, é a câmara municipal, que tem que mudar a lei da composição do Conselho. E quando chega lá na câmara, os diretor dos hospital vai lá e compra os vereador. Os vereador de Londrina: acho que uma das câmara mais corrupta que nós tem é em Londrina. A gente tem aí, 2,3,4 vereador que se vota com interesse do povo; o resto é tudo com interesse da iniciativa privada, do prefeito. É o pacote que não tem nem como levar e discutir."

As discussões iniciadas no momento da organização da $6^{a}$ Conferência Municipal de Saúde foram mais uma tentativa da alteração da composição do CMS, bem como as linhas gerais da política municipal de saúde.

(C) "Agora tá tendo, parece que a Secretaria ou o Conselho, sei lá. Tá chamando pra começar a discutir a organização da $6^{a}$ conferência. E aí a gente já tá conseguindo fazer algumas reuniões com os Conselhos Regionais, o $\mathrm{CDH}$, que é o Centro dos Direitos Humanos tá intermediando essas conversas. Criou-se lá uma comissão de saúde e aí a gente tem sentado pra discutir."

Existe grande possibilidade de que os conselhos de saúde regionais, em particular o CONSUL, obtenham a esperada modificação na composição do CMS, passando a figurar como conselheiros. 


\section{CONSIDERAÇÕES FINAIS}

\subsection{DA METODOLOGIA}

O conjunto de categorias analíticas construídas na estrutura metodológica deste estudo de caso resultou em um instrumental de grande utilidade na compreensão e discussão das informações obtidas pelo trabalho de campo. Uma vez realizadas as discussões, é possível admitir que a metodologia proposta foi suficiente para alcançar o objetivo geral do trabalho: analisar o papel do PROUNI-Londrina na organização dos movimentos populares de saúde na região Sul do município.

Sobre as categorias analíticas, a constante relação encontrada entre elas, mostrando, ao longo das discussões, um papel complementar de um tema em relação aos demais, teve êxito ao mostrar que o conjunto de parâmetros teóricos elaborados na forma de um marco conceitual foi suficiente para sustentar a interpretação da realidade observada durante o trabalho de campo.

\subsection{DOS RESULTADOS}

Ao longo dos oito anos do PROUNI-Londrina, foram muitos os resultados positivos em cada um dos três componentes, tanto de maneira isolada quanto em seu conjunto. Assim como inovações curriculares foram descobertas ou implantadas nos cursos da academia e novos instrumentos gerenciais foram criados e desenvolvidos pelos serviços de saúde, no âmbito comunitário, os avanços foram surpreendentes. 
A partir do apoio conferido às entidades de base dos movimentos populares de saúde e ao CONSUL, foi possível perceber uma transformação significativa nos estágios de articulação e organização vigentes no início do Projeto UNI em 1992 e o período atual. A formação e a capacitação de lideranças populares, a realização de intercâmbios internacionais, a aquisição e estruturação da sede do CONSUL, a viabilização de reuniões nas regiões rurais, a promoção de seminários e outros eventos com discussões sobre temas relacionados à saúde e participação, entre outras coisas, foram os alicerces de um processo de articulação e organização que já possui traços de certa solidez.

Ao mesmo tempo, a criação dos espaços de discussão entre os movimentos populares, a universidade e os serviços de saúde, paulatinamente, contribuiu para a apropriação de conhecimentos técnicos e políticos pelos representantes populares, proporcionando as bases de sustentação da autonomia do movimento. Esta autonomia pôde ser verificada principalmente a partir dos discursos críticos feitos em relação à organização dos serviços de saúde, à orientação do poder público municipal, bem como a certas posturas ainda conservadoras da universidade.

Apesar da marcante contribuição econômica dada pelo PROUNI no início das atividades de organização do CONSUL, o acúmulo de experiências inovadoras como várias das oficinas de geração de renda, das parcerias estabelecidas com escolas e creches, da constituição de comitês da cidadania reconhecidos pelo poder público, entre outras coisas, proporcionou aos movimentos a possibilidade de caminhar com as próprias pernas, de viabilizar novas cooperações e de iniciar as discussões sobre auto-sustentabilidade.

Grande parte dessas atividades foram desenvolvidas de forma estratégica, o que as consolidou como novas práticas políticas com o objetivo claro de ganhar representatividade para as instituições populares, à medida que ampliavam as suas bases de participação e conferiam a certo número de pessoas, a possibilidade de participar de atividades de geração de renda e de resgate moral, através do retorno ao trabalho. 
Através do apoio do PROUNI-Londrina, que pode ser caracterizado como financeiro, político, cultural e gerencial, notou-se um desenvolvimento significativo tanto no CONSUL quanto em várias de suas entidades constituintes. Com essa afirmação, pretende-se mostrar que a escolha do CONSUL, enquanto a organização (instituição) comunitária participante na gerência do PROUNI, não significou para os movimentos populares o distanciamento entre as bases e suas representações.

A articulação dos movimentos de base foi - e continua sendo - uma das estratégias mais bem sucedidas dos movimentos para seu crescimento e suas conquistas. Além disso, ao mesmo tempo que as lideranças da região, mantiveram seus olhares e compromissos com as bases populares, elas não perderam de vista os intercâmbios e articulações com outros setores da sociedade. A participação em espaços políticos nacionais e até mesmo internacionais trouxe importantes contribuições para os debates locais. Nestas participações, sempre houve colaboração direta do Projeto UNI.

Observando de forma sistêmica, foi possível verificar que as contribuições do Projeto UNI proporcionaram à comunidade a conquista de um bom nível de autonomia, circunstância diversas vezes abordada pelos atores entrevistados. Os benefícios estruturais obtidos pelo CONSUL e suas entidades de base, foram acompanhados de um crescente respeito pelas opiniões da comunidade, que como abordado nas discussões, em muitos momentos foi o componente que sustentou o desenvolvimento do Projeto.

A luta pela autonomia prossegue contudo, ao longo dos dias atuais. As entrevistas com atores da comunidade demonstram o desejo de que as entidades de base e o CONSUL sejam financeiramente auto-suficientes, a fim de as amarras que ainda existem em relação ao poder público, a partidos políticos e mesmo à universidade, sejam desfeitas.

Dentre as formas encontradas pela comunidade para buscar a autonomia e a independência necessárias, a acelerada organização de suas entidades é o que 
chama mais atenção. O CONSUL, através do fortalecimento de seus segmentos, conseguiu ampliar suas ações de forma significativa. As conquistas mais recentes, através do segmento mulheres e do segmento educação, são as que mais se destacam.

Em relação a isso, a possibilidade do uso das assessorias específicas e da incorporação de instrumentos gerenciais importantes aos movimentos populares, com destaque para o método PES, foi mais uma contribuição direta do PROUNILondrina para as organizações comunitárias.

Além de tais instrumentos técnicos, deve-se ainda classificar como fundamental a possibilidade de estabelecer a relação de parceria entre a academia, os serviços de saúde e a comunidade. Ainda que vários obstáculos estejam sendo encontrados pelo caminho, é visível o amadurecimento político das lideranças comunitárias, a partir da participação na CIGO, por exemplo. Como se costuma apresentar em alguns documentos produzidos pelo Projeto, a apropriação de conhecimentos pela comunidade trouxe grandes benefícios às lutas populares.

Em função das discussões apresentadas no capítulo anterior, tais benefícios podem ser objetivamente percebidos, ao se analisar os avanços relacionados à cultura política do movimento. Além dos avanços na construção de relações políticas com outros atores relacionados aos movimentos populares, tais como os demais conselhos de saúde regionais, movimentos estaduais e nacionais, grupos políticos locais, imprensa, etc., merecem destaque alguns pontos levantados nas discussões, resumindo os avanços:

a) a responsabilidade das lideranças;

b) a prioridade em formar atores conscientes de seus direitos e das questões políticas e sociais envolvidas nas lutas comunitárias;

c) a articulação das lutas locais com a temática das lutas populares mais amplas do País; 
d) a articulação entre visão local e visão global dos movimentos para a elaboração das ações;

e) a criação de espaços democráticos para a ação dos movimentos de base dentro do CONSUL;

f) o conhecimento de que, à medida que o movimento se desenvolve e se projeta politicamente, forças políticas externas começam a agir no sentido de romper a estrutura conquistada pelo movimento;

g) a necessidade de aprofundar as relações de parceria no PROUNI-Londrina e as relações políticas no município;

h) a valorização de posturas políticas independentes dos demais componentes UNI e dos partidos e forças políticas locais;

i) a visão dos próprios atores dos movimentos populares de que o trabalho tem tido grande impacto nas lutas populares;

j) o crescimento da visão crítica em relação às políticas públicas.

À medida que tal cultura tem sido construída, a comunidade passou a se dar conta do preço que se paga por poder interferir nas políticas locais. A orientação política do governo municipal pareceu se chocar com as demandas populares, chamando a atenção de vereadores e do próprio prefeito, para as organizações populares da região Sul. Recentes disputas eleitorais revelaram uma franca ingerência de vereadores da base do governo nos processos eleitorais, contribuindo para acirrar a disputa entre grupos de moradores por certas associações de bairro e de mulheres.

Tal disputa interferiu na comunidade, resultando no atraso de algumas atividades de organização do CONSUL e, principalmente, na diminuição do ritmo das conquistas para a região, à medida que muitas lideranças tiveram que 
concentrar esforços para que os movimentos populares não perdessem terreno para grupos oportunistas.

Mesmo em relação à ASMS, parceira da comunidade no Projeto, uma significativa resistência tem sido encontrada. Enquanto a CIGO tem procurado ser um espaço de implementação da parceria, tentando estabelecer um clima de respeito e cooperação, os caminhos tomados pela ASMS em relação à comunidade não têm sido democráticos.

Como exemplo, foi possível identificar que os conselhos de saúde das UBS da região Sul, além do CMS, têm dificultado a participação da comunidade, à medida que a orientação dos serviços de saúde tem partido da estrutura central da ASMS. São poucas as circunstâncias em que os conselhos locais de fato têm interferido na organização dos serviços. Apesar disso, a comunidade continua tentando estabelecer boas relações com as coordenadoras e equipes de saúde das UBS, acreditando na possibilidade de construírem juntas um serviço de saúde melhor para a região.

Em relação ao CMS, não apenas o CONSUL mas também os demais conselhos regionais (CONSOESTE, CONSLESTE, CONSNORTE $\mathrm{e}$ CONSCENTRO), reconhecem e anseiam por modificações na Lei Municipal 4.911/91, que instituiu o CMS, a fim de que se garanta uma melhor composição dos usuários dos serviços, que atualmente não contempla nenhum dos conselhos de saúde regionais.

Quanto aos demais conselhos de saúde regionais, não foram encontrados registros de que o CONSUL tenha exercido qualquer influência marcante nas demais organizações. Nos diálogos com atores ligados a elas, percebeu-se que existe grande fragilidade na autonomia desses conselhos, em sua articulação, e lentidão na construção de sua cultura política. 


\subsection{DOS DESAFIOS FUTUROS}

Desde sua fundação em 1991, o CONSUL tem assumido ao menos dois papéis elementares para a luta pela saúde:

a) Aparelho aglutinador de movimentos populares de base, cuja missão é de somar as diversas microagendas das mais de cem entidades de bairros e rurais, potencializando essas lutas, à medida que as insere em uma macroagenda do próprio CONSUL, a qual tem estado na pauta do poder público local, em outras organizações da sociedade, na imprensa e no Projeto UNI .

b) Aparelho estimulador dos movimentos populares de base, cuja missão é garantir o crescimento das discussões e da ampliação da participação nas bases do movimento, aumentando a capacidade de conquistas da base e fortalecendo a própria estrutura do CONSUL em um processo interativo.

Através desses papéis, para os quais existem inúmeras estratégias definidas - conforme demonstrado anteriormente - o CONSUL tem procurado exercer o papel que Ihe cabe dentro do SUS, qualificando a participação popular nas esferas do sistema de saúde, conforme garante a Lei Federal 8142/91. E esta tem sido, segundo GOHN (1997), a tônica dos movimentos de saúde da década de 90 .

Por estar inserido no movimento sanitário nacional, o CONSUL contribui, através de ações sócio-políticas, para a garantia sem restrições das doutrinas e princípios do SUS. Mantendo os movimentos populares com esse interesse comum, frente ao qual as disputas e conflitos continuarão se materializando, o CONSUL tende a fortalecer a identidade solidária construída entre seus atores, ao longo desses oito anos. 
O CONSUL tem a missão de gerar inovações nas esferas públicas e privadas, e assim tem feito; tem a missão de participar das lutas mais amplas da sociedade brasileira, e delas não tem fugido; tem a missão de participar das mudanças sociais históricas do país, e por elas tem lutado.

Para garantir seu desenvolvimento permanente, o momento desafia 0 CONSUL e as entidades a ele relacionadas a consolidar suas estruturas políticas e organizacionais, bem como as relações de parceria com os demais componentes do PROUNI-Londrina. É ainda fundamental que os movimentos populares procurem a visibilidade e a credibilidade necessárias a organizações de tamanha relevância social para o município.

A necessidade e as possibilidades de transformação na sociedade brasileira são muito grandes e a luta por melhores condições de vida e pela real implementação do SUS são duas de suas vertentes mais marcantes. Nesse cenário, as perspectivas criadas no Projeto UNI Londrina para a participação dos movimentos populares como agentes sociais de transformação, devem servir de reflexão para motivar ações que contribuam para o desenvolvimento de uma sociedade democrática e justa. 


\section{REFERÊNCIAS BIBLIOGRÁFICAS}

Almeida M. A organização de serviços de saúde a nível local: registros de uma experiência em processo. Rio de Janeiro; 1979. [Dissertação de Mestrado - Instituto de Medicina Social da Universidade Estadual do Rio de Janeiro].

Ammann SB. Ideologia do desenvolvimento de comunidade no Brasil. $8^{a}$ ed. São Paulo: Cortez; 1992.

Anais da $8^{a}$ Conferência Nacional de Saúde; 1986 mar 17-21; Brasília: Centro de Documentação do Ministério da Saúde; 1987.

Arouca ASS. Democracia é saúde. In: Anais da $8^{a}$ Conferência Nacional de Saúde; 1986 mar 17-21; Brasília: Centro de Documentação do Ministério da Saúde; 1987, p 35-42.

Baduy RS, Turini B. Desenvolvimento comunitário: reflexões sobre o papel do PROUNI-LD. Londrina: Centro de Ciências da Saúde; 1997.

Baduy RS, Gil CR, Gordan PA, Ito AM, Soares DA, Vannuchi MT. Desenvolvimento da parceria e mudança institucional no Projeto UNI Londrina 1991 - 1997: uma sistematização inicial. In: Fundação W. K. Kellogg. $1^{\circ}$ Seminário UNI de Sistematización, Parceria e Cambio Institucional. São Paulo, ago; 1997.

Bardin L. Análise de conteúdo. São Paulo: Persona; 1988.

Barrios SRL. Construindo um conceito democrático de saúde. Londrina: um estudo de caso. São Paulo; 1999. [Dissertação de Mestrado - Faculdade de Saúde Pública da Universidade de São Paulo].

Batista R, Carvalho BG, Silva FF, Turini B. Fortalecendo as organizações comunitárias e desenvolvendo a cidadania. Londrina: Centro de Ciências da Saúde; 1998. 
Bógus CM. Participação popular em saúde: formação política e desenvolvimento. São Paulo: Annablume/FAPESP; 1998.

Brasil. Constituição da República Federativa do Brasil. 10a ed. São Paulo: Saraiva; 1994.

Brasil. Lei 8.080 de 1990. In: Carvalho GI, Santos L. Sistema Único de Saúde: comentários à lei orgânica da saúde (Lei 8.080/90 e Lei 8.142/90). $2^{\mathrm{a}}$ ed. São Paulo: Hucitec; 1995a. p. 298-312.

Brasil. Lei 8.142 de 1990. In: Carvalho GI, Santos L. Sistema Único de Saúde: comentários à lei orgânica da saúde (Lei 8.080/90 e Lei 8.142/90). $2^{\mathrm{a}}$ ed. São Paulo: Hucitec; 1995b. p. 313-14.

Campos GW. A saúde pública e a defesa da vida. $2^{a}$ ed. São Paulo: Hucitec; 1994.

Carvalho IV. Conselhos de saúde no Brasil: participação cidadã e controle social. Rio de Janeiro: FASE/IBAM; 1995.

Castro MS. O sindicalismo na construção da democracia brasileira: a experiência e perspectivas da CUT. In: Hellmann M. Movimentos sociais e democracia no Brasil: sem a gente não tem jeito. São Paulo: Marco Zero; 1995. p. 101-33.

Chaves $M$, Kisil M. Programa UNI, uma nova iniciativa na educação dos profissionais de saúde. Battle Creek: W. K. Kellogg Foundation; 1994.

Cohn A. Saúde e cidadania: análise de uma experiência de gestão local. In: Eibenschutz $C$. Política de saúde: o público e o privado. Rio de Janeiro: FIOCRUZ; 1996. p. 315-27.

Conselho Municipal de Saúde de Londrina. Relatório de gestão 1993 - 1996. Londrina; 1996 
CONSUL. Síntese de atividades do Conselho de Saúde da Zona Sul. Londrina; 1997.

CONSUL. Força da população organizada em uma região saudável. Uma visão das lideranças comunitárias sobre as políticas públicas na Região Sul do Município de Londrina-PR. Londrina; 1998a.

CONSUL. Relatório do componente comunitário do PROUNI Londrina: 1991 1998. Londrina; $1998 \mathrm{~b}$.

Cordoni L. Medicina comunitária: emergência e desenvolvimento na sociedade brasileira. São Paulo; 1979. [Dissertação de Mestrado - Faculdade de Medicina da Universidade de São Paulo].

Costa M. Kellogg vai patrocinar biblioteca virtual: será na zona sul de Londrina e a tecnologia estará presente também nos bairros pobres. O Estado do Paraná, Curitiba, 1999 fev 28; cad 2:1.

Costa NR. Transição e movimentos sociais: contribuição ao debate da reforma sanitária. In: Costa NR, Minayo MC, Ramos CL, Stotz EN. Demandas populares, políticas públicas e saúde: movimentos sociais e cidadania. Petrópolis: Vozes/Rio de Janeiro: ABRASCO; 1989. v.2. p. 45-65.

Delgado MB, Soares V. O movimento de mulheres na transição democrática brasileira. In: Hellmann M. Movimentos sociais e democracia no Brasil: sem a gente não tem jeito. São Paulo: Marco Zero; 1995. p. 77-100.

Escorel S. Saúde: uma questão nacional. In: Reforma sanitária: em busca de uma teoria. $2^{\mathrm{a}}$ ed. Rio de Janeiro: ABRASCO/São Paulo: Cortez; 1995. p. 181-92.

Escorel S. Reviravolta na saúde: origem e articulação do movimento sanitário. Rio de Janeiro: FIOCRUZ; 1998.

Feuerwerker LC. As comunidades e o programa UNI. UNI Letter 1998; (13): 2-3. 
Feuerwerker LC, Sena R. A construção de novos modelos acadêmicos, de atenção à saúde e de participação social. In: Almeida MJ, Feuerwerker L, Llanos M. A educação dos profissionais de saúde na América Latina. Teoria e prática de um momento de mudança. São Paulo: Hucitec/Londrina: UEL; 1999.

Fleury S. Reforma sanitária: em busca de uma teoria. $2^{a}$ ed. Rio de Janeiro: ABRASCO/São Paulo: Cortez; 1995. p. 17-46.

Fleury S. Saúde e democracia: a luta do CEBES. São Paulo: Lemos; 1997. p. 25-41.

Fujiwara CE, Gil CR, Hirata LT, Machado RA, Rocha ML. Algumas reflexões sobre o desenvolvimento do Projeto UNI Londrina: a visão do componente serviços. Londrina; 1997.

Fundação IBGE. Contagem da população: 1996. Rio de Janeiro; 1997. 2.v.

Fundação W. K. Kellogg. Evaluacion del conjunto de proyectos UNI: cluster UNI. Informe del primer periodo. [s.I.]; 1995.

Fundação W. K. Kellogg. Informe de avaliação de cluster dos projetos UNI-2: segundo período. [s.I.]; 1997a.

Fundação W. K. Kellogg. Desarrollo integrado de los componentes comunidad, servicios e academia. $2^{\circ}$ Seminário de Sistematización del Programa UNI. Miami sep; 1997b.

Goldim JR. Manual de iniciação à pesquisa em saúde. Porto Alegre: Dacasa; 1997.

Gohn MG. Teoria dos movimentos sociais. São Paulo: Loyola; 1997.

Hellmann M. Movimentos sociais e democracia no Brasil: sem a gente não tem jeito. São Paulo: Marco Zero; 1995. p. 9-23. 
Izquierdo J. A comunidade como componentes essencial dos projetos UNI. In: Chaves M, Kisil M. Programa UNI, uma nova iniciativa na educação dos profissionais de Saúde. Battle Creek: W. K. Kellogg Foundation; 1994. p. 51-61.

Jabobi PR. Movimentos sociais e Estado: efeitos político-institucionais da ação coletiva. In: Costa NR, Minayo MC, Ramos CL, Stotz EN. Demandas populares, políticas públicas e saúde: movimentos sociais e cidadania. Petrópolis: Vozes/Rio de Janeiro: ABRASCO; 1989. v.2. p. 13-35.

Kisil M. Uma estratégia para a reforma sanitária: a iniciativa UNI. Divulgação Saúde Debate 1996; (12): 5-14.

López LG. Uma aproximação à avaliação da participação comunitária em SILOS: o projeto UNI Marília. São Paulo; 1996. [Dissertação de Mestrado Faculdade de Saúde Pública da Universidade de São Paulo].

Magendzo S, Toledo MI. Planificación participativa y salud comunitaria: una guia para la accion. Santiago (Chile): Radda Barnen; 1992.

Merhy EE. Saúde e movimento popular: o relato de uma experiência. Cedes, 1987; (4): 44-53.

Minayo MC. $O$ desafio do conhecimento. $3^{\circ}$ ed. Rio de Janeiro: ABRASCO/São Paulo: Hucitec; 1994.

Neto ER. A via do parlamento. In: Fleury S. Saúde e democracia: a luta do CEBES. São Paulo: Lemos; 1997. p. 63-92.

Oliveira JA. Reformas e reformismos: para uma teoria política da reforma sanitária (ou, reflexões sobre a reforma sanitária de uma perspectiva popular). In: Costa NR, Minayo MC, Ramos CL, Stotz EN. Demandas populares, políticas públicas e saúde: movimentos sociais e cidadania. Petrópolis: ABRASCO/Vozes; 1989. v.1. p. $13-44$. 
Pereira MP. A comunidade fazendo sua história. Divulgação Saúde Debate 1994; (9): 71-2.

Prefeitura do Município de Londrina. Autarquia dos Serviços Municipais de Saúde. Rumos da saúde para Londrina: Plano Municipal de Saúde para o biênio 1996 - 1997. Londrina; 1996.

Ramos CL. Conselhos de saúde e controle social. In: Eibenschutz C. Política de saúde: o público e o privado. Rio de Janeiro: FIOCRUZ; 1996. p. 329-44.

Rodello CCM. A saúde como a gente quer: a participação e o controle social enquanto estratégias facilitadoras do acesso da população à saúde. São Paulo; 1998. [Dissertação de Mestrado - Faculdade de Saúde Pública da Universidade de São Paulo].

Sader E. Quando novos personagens entraram em cena: experiências e lutas dos trabalhadores da grande São Paulo: 1970 - 1980. $2^{\mathrm{a}}$ ed. São Paulo: Paz e Terra; 1995.

Santos MTN. Estudo sobre a participação da população civil organizada nas cinco conferências municipais de saúde de Londrina. Londrina; 1998. [Monografia - Centro de Ciências da Saúde da Universidade Estadual de Londrina].

Silva SF. A construção do SUS a partir do município. São Paulo: Hucitec; 1996.

Smeke EL. Educação, saúde e movimento popular. Saúde Debate 1990; (28): 525 .

Souza ML. Desenvolvimento de comunidade e participação. $4^{\mathrm{a}}$ ed. São Paulo: Cortez; 1993. 
Universidade Estadual de Londrina (UEL). Projeto UNI Londrina: uma nova iniciativa na educação dos profissionais de saúde: união com a comunidade: versão resumida. Londrina; 1992.

Universidade Estadual de Londrina (UEL). PROUNI-LD FASE II: uma nova iniciativa na educação dos profissionais de saúde: união com a comunidade: anteprojeto. Londrina; 1996.

Valla VV. Participação popular e saúde: a questão da capacitação técnica no Brasil. In: Stotz EN, Valla VV. Participação popular, educação e saúde: teoria e prática. $2^{\mathrm{a}}$ ed. Rio de Janeiro: Relume Dumará; 1993. p. 58-90.

Westphal MF. Participação popular e políticas municipais de saúde: Cotia e Vargem Grande Paulista. São Paulo; 1992. [Tese de Livre Docência - Faculdade de Saúde Pública da Universidade de São Paulo].

Zioni F. Mulheres e crianças primeiro! O caráter da intervenção do Estado no grupo materno-infantil da colônia ao milagre brasileiro. São Paulo; 1988. [Dissertação de Mestrado - Faculdade de Saúde Pública da Universidade de São Paulo].

Zioni F. Pesquisa participante: relato e avaliação de uma experiência. São Paulo; 1994. [Tese de Doutorado - Faculdade de Saúde Pública da Universidade de São Paulo]. 


\section{ANEXOS}

1. Relação dos projetos UNI na América Latina.

2. Variação do produto interno bruto brasileiro entre os anos 1960 e 1999.

3. Londrina: posição geográfica no Paraná e no Brasil; identificação da zona urbana e dos distritos rurais.

4. Pirâmide etária do município de Londrina em 1991.

5. Áreas de abrangência das UBS da zona urbana de Londrina.

6. Áreas de abrangência das UBS da zona urbana sul de Londrina.

7. Unidades Básicas de Saúde em Londrina

8. Roteiros das entrevistas

9. Oficina de síntese do IV Encontro Nacional de Lideranças Comunitárias UNI.

10. Entidades componentes do CONSUL.

11. Organograma do CONSUL.

12. Figura representativa das relações entre os componentes dos projetos UNI.

13. Panfleto recolhido durante o trabalho de campo. 